OPEN ACCESS

Edited by: John - Maher,

King's College London, United Kingdom

Reviewed by:

Caroline Hull,

Leucid Bio, United Kingdom

Dean Anthony Lee,

The Research Institute at Nationwide Children's Hospital, United States Robert J. Canter, University of California, Davis, United States

*Correspondence: Mohan C. Vemuri mohan.vemuri@thermofisher.com

Specialty section: This article was submitted to

Cancer Immunity and Immunotherapy,

a section of the journal

Frontiers in Immunology

Received: 28 June 2021 Accepted: 01 November 2021 Published: 01 December 2021

Citation:

Heipertz EL, Zynda ER, Stav-Noraas TE, Hungler AD, Boucher SE, Kaur N and Vemuri MC

(2021) Current Perspectives on

"Off-The-Shelf" Allogeneic NK and CAR-NK Cell Therapies.

Front. Immunol. 12:732135. doi: 10.3389/fimmu.2021.732135

\section{Current Perspectives on "Off-The-Shelf" Allogeneic NK and CAR-NK Cell Therapies}

\author{
Erica L. Heipertz ${ }^{1}$, Evan R. Zynda ${ }^{2}$, Tor Espen Stav-Noraas ${ }^{3}$, Andrew D. Hungler ${ }^{1}$, \\ Shayne E. Boucher ${ }^{1}$, Navjot Kaur ${ }^{1}$ and Mohan C. Vemuri ${ }^{1 *}$ \\ ${ }^{1}$ Cell \& Gene Therapy, Thermo Fisher Scientific, Frederick, MD, United States, ${ }^{2}$ BioProduction, Thermo Fisher Scientific, \\ Grand Island, NY, United States, ${ }^{3}$ BioProduction, Thermo Fisher Scientific, Oslo, Norway
}

Natural killer cells (NK cells) are the first line of the innate immune defense system, primarily located in peripheral circulation and lymphoid tissues. They kill virally infected and malignant cells through a balancing play of inhibitory and stimulatory receptors. In preclinical investigational studies, NK cells show promising anti-tumor effects and are used in adoptive transfer of activated and expanded cells, ex-vivo. NK cells express costimulatory molecules that are attractive targets for the immunotherapy of cancers. Recent clinical trials are investigating the use of CAR-NK for different cancers to determine the efficiency. Herein, we review NK cell therapy approaches (NK cell preparation from tissue sources, ways of expansion ex-vivo for "off-the-shelf" allogeneic cell-doses for therapies, and how different vector delivery systems are used to engineer NK cells with CARs) for cancer immunotherapy.

\section{Keywords: natural killer cells, CAR-NK cells, immunotherapy, NK cell expansion, lentiviral delivery, AAV delivery,} killer immune receptors, GMP manufacturing

\section{NATURAL KILLER CELL BIOLOGY}

Human natural killer (NK) cells are innate cytotoxic lymphoid cells derived from CD34+ precursors originating from hematopoietic stem cells $(1,2)$ and play an essential role in tumor surveillance. Unlike T cells, NK cells can kill malignant cells in an antigen-independent manner and have shown promise in a number of clinical trials involving both solid and hematological cancers (3). NK cells do not require HLA matching. Their ability to act in an antigen-independent manner makes them a viable option for an "off the shelf" therapy that can be manufactured on a large scale and easily distributed to cancer patients.

NK cells are subdivided into two populations based on their relative expression of CD56 (neural cell adhesion molecule; NCAM) and CD16: immature CD56 $6^{\text {bright }} \mathrm{CD} 16^{\text {neg }} \mathrm{NK}$ cells, and mature $\mathrm{CD} 56^{\mathrm{dim}} \mathrm{CD} 16^{\text {pos }} \mathrm{NK}$ cells (4). The CD56 ${ }^{\text {bright }}$ population accounts for $10 \%$ of NK cells circulating in the blood and are located primarily in lymph nodes. Immature CD56 $6^{\text {bright }} \mathrm{NK}$ cells have an immunoregulatory function and produce cytokines, such as interferon-gamma (IFN- $\gamma$ ), TNFo, TNF- $\beta$, IL-10, and GM-CSF (5). In contrast, the mature CD56 ${ }^{\mathrm{dim}} \mathrm{CD} 16^{\mathrm{pos}}$ population accounts for up to $90 \%$ of the circulating NK cells (6). The key function of mature CD56 ${ }^{\mathrm{dim}} \mathrm{CD} 16^{\mathrm{pos}} \mathrm{NK}$ cells is natural and $\mathrm{Ab}$-mediated cell cytotoxicity. Mature CD56 ${ }^{\mathrm{dim}} \mathrm{NK}$ cells express high amounts of killer cell immunoglobulin receptors (KIRs) (7). 
The mechanism for the transition from CD56 ${ }^{\text {bright }}$ to CD56 ${ }^{\text {dim }}$ is still widely unknown, but the change in surface markers is a major indicator for transitioning to maturity $(2,7)$. CD16, CD27, CD56, CD57, and perforin are all markers for NK cell maturation $(7,8)$. CD27 is a marker of immature NK cells, associated with the TNF $\alpha$ receptor group and found on three times as many immature CD56 ${ }^{\text {bright }}$ as mature CD56 ${ }^{\text {dim }}$ (7). Inversely CD57 and perforin are markers for terminal maturity and are highly expressed on mature NK cells $(7,9)$.

Located throughout the body, NK cells represent $5-20 \%$ of all lymphocytes in the blood and organs with high concentrations in the bone marrow, spleen, liver, lungs, skin, kidneys, uterus, and secondary lymphoid tissue $(8,10)$. The tissue-specific location has been shown to have a significant impact on NK cell functionality and cytokine production. Mature NK cells in the lung are shown to produce higher amounts of granzyme B, a serine protease associated with cytotoxicity, than those NK cells found in the lymph nodes or gut (8).

NK cells secrete a number of pro-inflammatory cytokines, such as TNF and IFN- $\gamma$ that stimulate an adaptive immune response and prevent tumor angiogenesis (5). The production levels of IFN- $\gamma$ and TNFo from NK cells can be stimulated through various cytokines such as IL-12, IL-15, and IL-18 (8).

NK cells function by killing virally infected, stressed, and cancerous cells in an antigen-independent manner $(1,2,8)$. Additionally, NK cells work to activate other immune cells using co-stimulatory signals (2). NK cell's cytolytic function is based on an array of activation and inhibitory signals (Figure 1) as well as self-major histocompatibility complexes (MHC) class I molecules $(1,2)$. NK cells recognize target cell MHC class I molecules which bind to the NK cell KIRs allowing the NK to identify "self." This self-identification inhibits the cytotoxic activity against normal cells $(1,2,7)$. In addition to preventing cytotoxic function, this binding also prevents inflammation and helps with the "licensing" of the immature NK cells (7). Tumor cells often downregulate MHC class I expression to avoid lysis by cytotoxic T cells. Additionally, DNA damage and cellular stress upregulates tumor ligands' expression on malignant cells, which are recognized by $\mathrm{NK}$ cell-activating receptors (Figure 2). NK cells will trigger cellmediated lysis (1) if a cell down-regulates its MHC class I molecules and upregulates activation ligands.

Once a cell is designated as infected, stressed, or cancerous, NK cells work to kill it through a direct release of cytolytic granules containing perforin and granzyme $\mathrm{B}$. The contents of cytolytic granules are released from the cell via degranulation (Figure 2). The granules from the NK cell form a synapse with the target cell, releasing the cytolytic contents. Perforin and granzyme B are key components of cytolytic granules and trigger apoptosis through caspase-dependent and independent mechanisms. Perforin aids in the entry of the granzyme B into the target cell, which ultimately leads to target cell death (11).

In addition to direct lysis of malignant or virally infected cells, CD56 ${ }^{\text {dim }} \mathrm{CD} 16^{\text {pos }} \mathrm{NK}$ cells mediate antibody-dependent cellular cytotoxicity (ADCC). ADCC is triggered when $\mathrm{NK}$ cells recognize an antibody opsonized target cell. The binding of
CD16 with the Fc portion of IgG antibodies trigger the release of perforin and granzyme B which lyse the target cell (11). ADCC is provoked by several therapeutic monoclonal antibodies (mAbs) and may enhance the homing and efficacy of NK cell therapy (12).

\section{NK CELL-BASED STRATEGIES IN CLINICAL TRIALS TARGETING DIFFERENT INDICATIONS}

Autologous and allogeneic NK cell therapies have shown great potential in preclinical studies and clinical trials. Different strategies are considered in clinical trials using NK cells for cancer therapies, including utilizing an agonist to NK cell activation receptors (mABs; transtuzumab, rituximab, etc., + IL-2 and anti PD1) or by blocking NK cells inhibitory receptor signals with mABs to KIR (NKG2A-CD94 or with CTLA-4 and PD-1 checkpoint inhibitor) (13). Recent findings demonstrate the potential of allogeneic NK cells for hematological malignancies and solid tumors (14). Unlike T cells, NK cells do not induce graft-versus-host-disease (GVHD) and their alloreactivity is enhanced under KIR mismatch with HLA ligands on cancer cells (15). Several clinical trials have highlighted the safety of the allogeneic transfer of NK cells (16). Allogeneic NK cells were used to target different cancers including hematological malignancies, lymphoma, leukemia, and solid tumors such as melanoma, neuroblastoma, gastric cancers, ovarian and breast tumors (Table 1).

An "off the shelf" NK cell therapy solves the one-donor, onepatient limitation that makes -autologous cell therapy processes labor-intensive. A critical step to enable allogeneic NK cell-based therapies would require a healthy donor source for NK cells and expanding to clinically relevant doses. Most clinical trials of NK cells require large numbers of cells for infusion, ranging from $5 \times 10^{6}$ to $1 \times 10^{8} \mathrm{CD} 3^{\text {neg }} \mathrm{CD} 56^{\text {pos }} \mathrm{NK}$ cells per kilogram body weight (5).

\section{SOURCES OF NATURAL KILLER CELLS FOR IMMUNOTHERAPY}

NK cells for therapy can be acquired from various sources such as umbilical cord blood (UCB) (17), peripheral blood (PB) (18, 19), human embryonic stem cells (hESCs) or induced pluripotent stem cells (iPSCs) (20) as well as cells lines such as NK-92 (21). To date, most of the NK cell clinical trials are based on UCB-NK cells, PB-NK cells, and the lymphoma-derived NK cell line NK-92. There are critical challenges in the manufacturing process of the final therapeutic cell doses. For example, isolation and expansion of PB-NK cells and UCB-NK cells result in a mixed composition (22). The cell line NK-92 is derived from a cancer patient with non-Hodgkin lymphoma; thus, the cells need to be irradiated before infusion, limiting the 


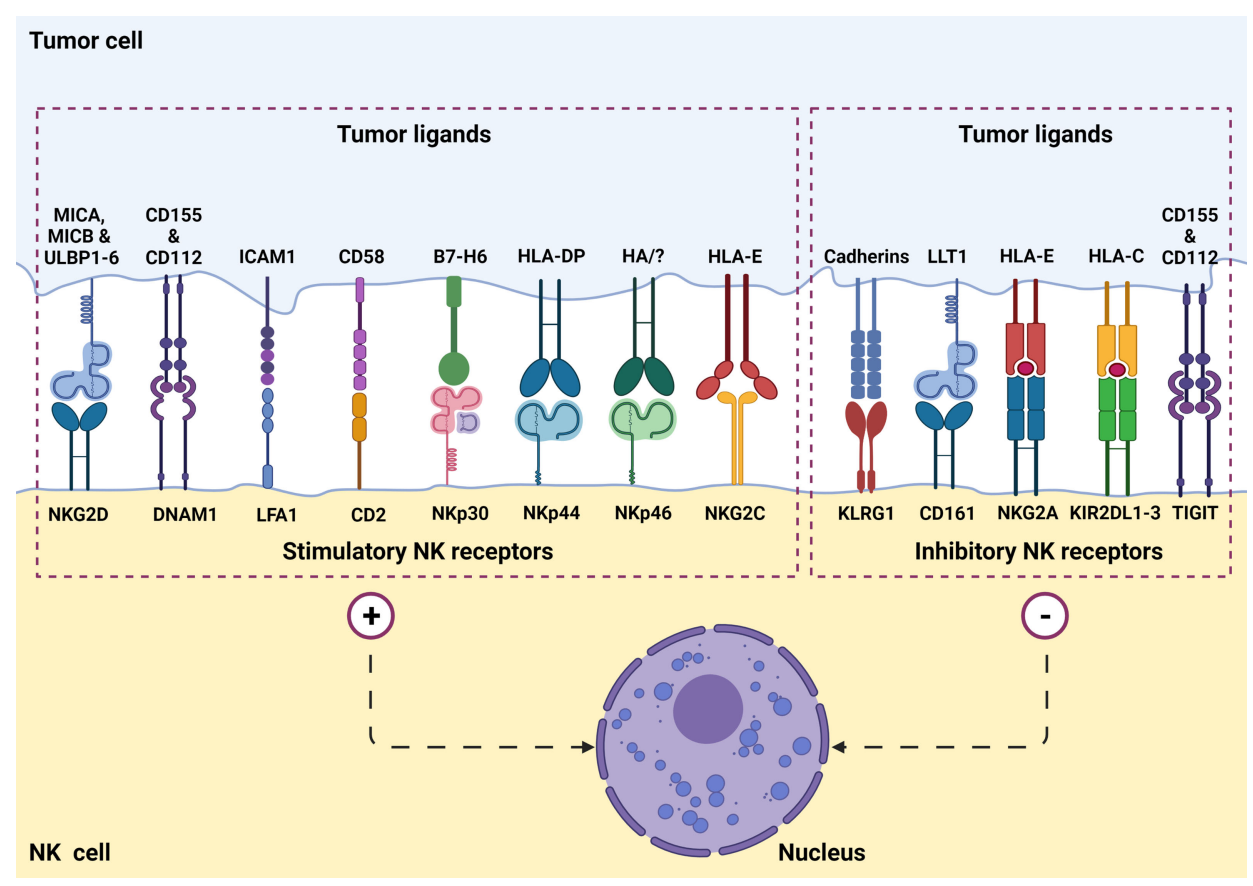

FIGURE 1 | NK cell surface receptors and ligands on tumor cells are involved in tumor recognition. NK cells express a set of stimulatory (or activation) receptors as well as inhibitory receptors to recognize healthy cells and aberrant cells such as virus-infected or a potential tumorigenic cell through MHC-1 receptor appearance.

NK cell persistence (23). In contrast to these limitations, hESCNK cells and iPSC-NK cells are more homogenous and can be generated in sufficient cell numbers for allogeneic clinical use (24). Pluripotent (hESC/PSC) derived NK cells can result in allogeneic therapy providing a standard cell-based treatment option for different diseases (24-26). Processing workflow of NK cell isolation from different donor sources through expansion for adaptive transfer is described (Figure 3).
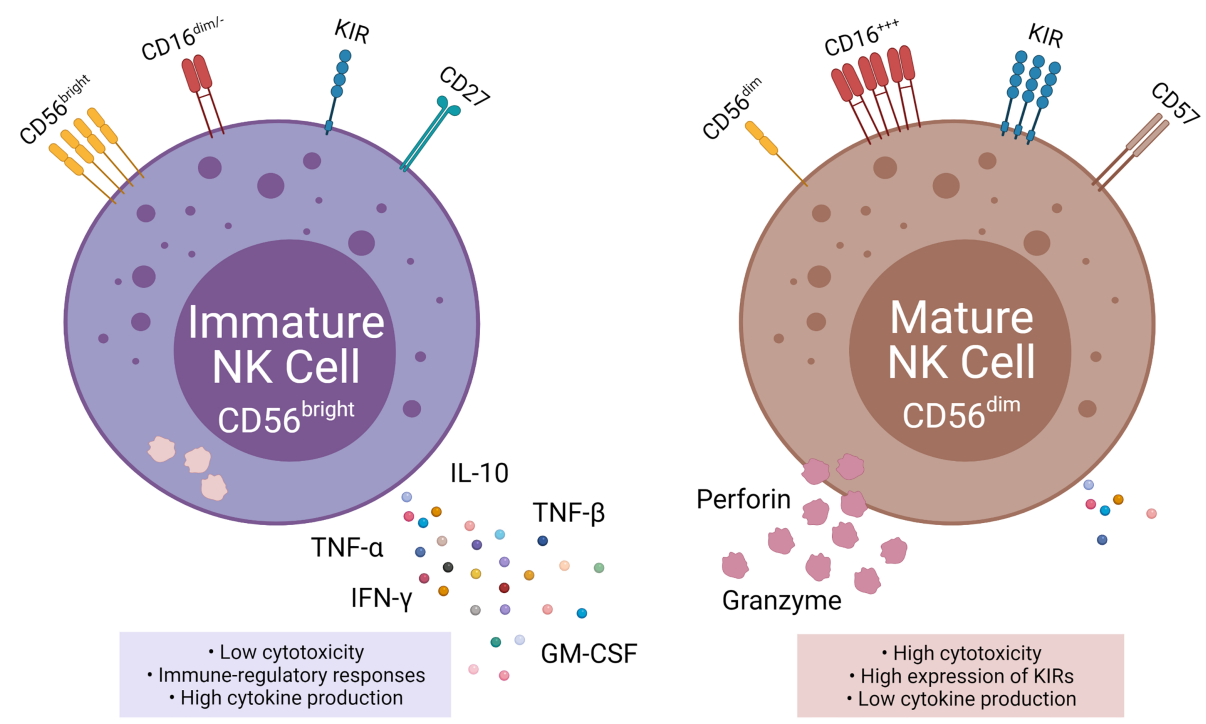

FIGURE 2 | Phenotypic and functional properties of immature (left) and mature (right) NK cells. Immature NK cells express CD56 ${ }^{\text {bright }}$, absent, or CD16 dim , low KIR, and CD27 and are also known as NK ${ }^{\text {regulatory }}$ that exhibit low cytotoxicity, but high cytokine production. Mature NK cells, in contrast, express CD56 dim, high CD16, high KIRs, and CD57 and are also knows as NK ${ }^{\text {cytotoxic }}$ that exhibit high cytotoxicity and low cytokine production. 
TABLE 1 | Completed allogeneic NK cell clinical trials.

\begin{tabular}{|c|c|c|c|c|c|c|c|c|c|c|c|}
\hline & NCT Number & Title & $\begin{array}{l}\text { NK Cell } \\
\text { source }\end{array}$ & Status & Conditions & Interventions & $\begin{array}{l}\text { Clinical trial } \\
\text { phase }\end{array}$ & Population & $\begin{array}{c}\text { Sponsor/ } \\
\text { Collaborators }\end{array}$ & Dates & Locations / Outcome \\
\hline 1 & NCT03358849 & $\begin{array}{l}\text { Phase } 1 \text { Clinical Trial } \\
\text { to Evaluate the Safety } \\
\text { of Allogeneic NK Cell } \\
\text { ("SMT-NK") Cell } \\
\text { Therapy in Advanced } \\
\text { Biliary Tract Cancer }\end{array}$ & Not available & $\begin{array}{l}\text { Completed: } \\
\text { No results } \\
\text { posted }\end{array}$ & $\begin{array}{l}\text { - Advanced Biliary } \\
\text { Tract Cancer }\end{array}$ & $\begin{array}{l}\text { - Biological: } \\
\text { Natural killer cell }\end{array}$ & $\begin{array}{l}\text { Study Type: } \\
\text { Interventional } \\
\text { Phase: } \\
\text { Phase } 1\end{array}$ & $\begin{array}{l}\text { Enrollment: } \\
9 \\
\text { Age: } \\
18 \text { Years to } \\
75 \text { Years } \\
\text { (Adult, } \\
\text { Older Adult) } \\
\text { Sex: } \\
\text { All }\end{array}$ & $\begin{array}{l}\text { - Yonsei } \\
\text { University }\end{array}$ & $\begin{array}{l}\text { Study Start: } \\
\text { October 17, } \\
2017 \\
\text { rimary } \\
\text { Completion: } \\
\text { September } \\
27,2018 \\
\text { Last } \\
\text { Update } \\
\text { Posted: } \\
\text { January 16, } \\
2019\end{array}$ & $\begin{array}{l}\text { - Division of } \\
\text { Gastroenterology, } \\
\text { Department of Internal } \\
\text { Medicine, Yonsei } \\
\text { University College of } \\
\text { Medicine, Seoul, Korea, } \\
\text { Republic of }\end{array}$ \\
\hline 2 & NCT02008929 & $\begin{array}{l}\text { to Evaluate the } \\
\text { Efficacy and Safety of } \\
\text { MG4101(Ex Vivo } \\
\text { Expanded Allogeneic } \\
\text { NK Cell) }\end{array}$ & $\begin{array}{l}\text { Allogeneic } \\
\text { expanded NK } \\
\text { Cells }\end{array}$ & $\begin{array}{l}\text { Completed: } \\
\text { No results } \\
\text { posted }\end{array}$ & $\begin{array}{l}\text { - Hepatocellular } \\
\text { Carcinoma }\end{array}$ & $\begin{array}{l}\text { - Biological: } \\
\text { MG4101 }\end{array}$ & $\begin{array}{l}\text { Study Type: } \\
\text { Interventional } \\
\text { Phase: } \\
\text { Phase } 2\end{array}$ & $\begin{array}{l}\text { Enrollment: } \\
5 \\
\text { Age: } \\
20 \text { Years to } \\
69 \text { Years } \\
\text { (Adult, } \\
\text { Older Adult) } \\
\text { Sex: } \\
\text { All }\end{array}$ & $\begin{array}{l}\text { - Samsung } \\
\text { Medical Center }\end{array}$ & $\begin{array}{l}\text { Study Start: } \\
\text { August } \\
2014 \\
\text { Last Update } \\
\text { Posted: } \\
\text { December } \\
\text { 3, } 2015\end{array}$ & $\begin{array}{l}\text { - Samsung Medical } \\
\text { Center, Seoul, Korea, } \\
\text { Republic of }\end{array}$ \\
\hline 3 & NCT01212341 & $\begin{array}{l}\text { Allogeneic Natural } \\
\text { Killer (NK) Cell Therapy } \\
\text { in Patients With } \\
\text { Lymphoma or Solid } \\
\text { Tumor }\end{array}$ & $\begin{array}{l}\text { Allogeneic NK } \\
\text { Cells }\end{array}$ & $\begin{array}{l}\text { Completed } \\
\text { - No results } \\
\text { posted }\end{array}$ & $\begin{array}{l}\text { - Malignant } \\
\text { Lymphomas } \\
\text { - Solid Tumors }\end{array}$ & $\begin{array}{l}\text { - Biological: } \\
\text { Allogeneic NK cells }\end{array}$ & $\begin{array}{l}\text { Study Type: } \\
\text { Interventional } \\
\text { Phase: } \\
\text { Phase } 1\end{array}$ & $\begin{array}{l}\text { Enrollment: } \\
18 \\
\text { Age: } \\
18 \text { Years } \\
\text { and older } \\
\text { (Adult, } \\
\text { Older Adult) } \\
\text { Sex: } \\
\text { All }\end{array}$ & $\begin{array}{l}\text { - Seoul } \\
\text { National } \\
\text { University } \\
\text { Hospital } \\
\text { - Green Cross } \\
\text { Corporation }\end{array}$ & $\begin{array}{l}\text { Study Start: } \\
\text { September } \\
2010 \\
\text { Primary } \\
\text { Completion: } \\
\text { August } \\
2012 \\
\text { Last Update } \\
\text { Posted: } \\
\text { August 19, } \\
2013\end{array}$ & $\begin{array}{l}\text { - Seoul National } \\
\text { University Hospital, Seoul, } \\
\text { Korea, Republic of }\end{array}$ \\
\hline 4 & NCT00383994 & $\begin{array}{l}\text { Immunotherapy With } \\
\text { NK Cell, Rituximab } \\
\text { and Rhu-GMCSF in } \\
\text { Non-Myeloablative } \\
\text { Allogeneic Stem Cell } \\
\text { Transplantation }\end{array}$ & $\begin{array}{l}\text { Blood derived } \\
\text { NK Cells }\end{array}$ & $\begin{array}{l}\text { Completed } \\
\text { No resultrs } \\
\text { posted }\end{array}$ & $\begin{array}{l}\text { - Lymphoma } \\
\text { - Leukemia } \\
\text { - Transplantation, } \\
\text { Stem Cell } \\
\text { - Lymphoid } \\
\text { Malignancies } \\
\text { - Disorder Related to } \\
\text { Transplantation }\end{array}$ & $\begin{array}{l}\text { - Drug: GM-CSF } \\
\text { - Drug: Rituximab } \\
\text { - Biological: NK } \\
\text { Cell Infusion }\end{array}$ & $\begin{array}{l}\text { Study Type: } \\
\text { Interventional } \\
\text { Phase: } \\
\text { Phase } 1\end{array}$ & $\begin{array}{l}\text { Enrollment: } \\
6 \\
\text { Age: } \\
\text { Child, } \\
\text { Adult, } \\
\text { Older Adult } \\
\text { Sex: } \\
\text { All }\end{array}$ & $\begin{array}{l}\text { - M.D. } \\
\text { Anderson Cancer } \\
\text { Center • Bayer } \\
\text { Healthcare } \\
\text { Pharmaceuticals, } \\
\text { Inc./Bayer } \\
\text { Schering Pharma }\end{array}$ & $\begin{array}{l}\text { Study Start: } \\
\text { September } \\
2006 \\
\text { Primary } \\
\text { Completion: } \\
\text { July 22, } \\
2019 \\
\text { Last Update } \\
\text { Posted: July } \\
\text { 31, 2019 }\end{array}$ & $\begin{array}{l}\text { - University of Texas MD } \\
\text { Anderson Cancer Center, } \\
\text { Houston, Texas, United } \\
\text { States }\end{array}$ \\
\hline 5 & NCT00402558 & $\begin{array}{l}\text { Alloreactive NK Cells } \\
\text { for Allogeneic Stem } \\
\text { Cell Transplantation for } \\
\text { Acute Myeloid } \\
\text { Leukemia (AML) and } \\
\text { Myelodysplastic } \\
\text { Syndrome (MDS) }\end{array}$ & $\begin{array}{l}\text { Completed - } \\
\text { no results } \\
\text { posted }\end{array}$ & $\begin{array}{l}\text { Completed } \\
\text { No results } \\
\text { posted }\end{array}$ & $\begin{array}{l}\text { - Myelodysplastic } \\
\text { Syndrome } \\
\text { - Leukemia }\end{array}$ & $\begin{array}{l}\text { - Drug: } \\
\text { Thymoglobulin } \\
\text { - Drug: Busulfan } \\
\text { - Drug: } \\
\text { Fludarabine } \\
\text { - Procedure: } \\
\text { Alloreactive NK } \\
\text { Infusion }\end{array}$ & $\begin{array}{l}\text { Study Type: } \\
\text { Interventional } \\
\text { Phase: } \\
\text { Phase } 1\end{array}$ & $\begin{array}{l}\text { Enrollment: } \\
15 \\
\text { Age: } \\
\text { up to } 70 \\
\text { Years } \\
\text { (Child, } \\
\text { Adult, } \\
\text { Older Adult) }\end{array}$ & $\begin{array}{l}\text { - M.D. } \\
\text { Anderson Cancer } \\
\text { Center }\end{array}$ & $\begin{array}{l}\text { Study Start: } \\
\text { May } 2006 \\
\text { Primary } \\
\text { Completion: } \\
\text { April } 2014 \\
\text { Last Update } \\
\text { Posted: May } \\
\text { 8, 2015 }\end{array}$ & $\begin{array}{l}\text { - UT MD Anderson } \\
\text { Cancer Center, Houston, } \\
\text { Texas, United States }\end{array}$ \\
\hline
\end{tabular}




\begin{tabular}{|c|c|c|c|c|c|c|c|c|c|c|}
\hline NCT Number & Title & $\begin{array}{l}\text { NK Cell } \\
\text { source }\end{array}$ & Status & Conditions & Interventions & $\begin{array}{l}\text { Clinical trial } \\
\text { phase }\end{array}$ & Population & $\begin{array}{l}\text { Sponsor/ } \\
\text { Collaborators }\end{array}$ & Dates & Locations / Outcome \\
\hline & & & & & $\begin{array}{l}\text { - Drug: G-CSF } \\
\text { - Drug: } \\
\text { Tacrolimus } \\
\text { - Drug: } \\
\text { Methotrexate } \\
\text { - Drug: } \\
\text { Interleukin-2 }\end{array}$ & & $\begin{array}{l}\text { Sex: } \\
\text { All }\end{array}$ & & & \\
\hline NCT01853358 & $\begin{array}{l}\text { Phase I of Infusion of } \\
\text { Selected Donor NK } \\
\text { Cells After Allogeneic } \\
\text { Stem Cell } \\
\text { Transplantation }\end{array}$ & $\begin{array}{l}\text { HLA identical } \\
\text { allogeneic NK } \\
\text { Cells }\end{array}$ & $\begin{array}{l}\text { Completed- } \\
\text { Phase 1-No } \\
\text { results } \\
\text { posted }\end{array}$ & $\begin{array}{l}\text { - Hematological } \\
\text { Malignancy }\end{array}$ & $\begin{array}{l}\text { - Biological: NK } \\
\text { Cell infusion }\end{array}$ & $\begin{array}{l}\text { Study Type: } \\
\text { Interventional } \\
\text { Phase: } \\
\text { Phase } 1\end{array}$ & $\begin{array}{l}\text { Enrollment: } \\
17 \\
\text { Age: } \\
18 \text { Years to } \\
70 \text { Years } \\
\text { (Adult, } \\
\text { Older Adult) } \\
\text { Sex: } \\
\text { All }\end{array}$ & $\begin{array}{l}\text { - Institut Paoli- } \\
\text { Calmettes }\end{array}$ & $\begin{array}{l}\text { Study Start: } \\
\text { April } 2013 \\
\text { Primary } \\
\text { Completion: } \\
\text { March 15, } \\
2018 \\
\text { Last Update } \\
\text { Posted: July } \\
\text { 12, } 2018\end{array}$ & $\begin{array}{l}\text { - Institut Paoli- } \\
\text { Calmettes, Marseille, } \\
\text { France }\end{array}$ \\
\hline NCT01287104 & $\begin{array}{l}\text { A Phase I Study of NK } \\
\text { Cell Infusion Following } \\
\text { Allogeneic Peripheral } \\
\text { Blood Stem Cell } \\
\text { Transplantation From } \\
\text { Related or Matched } \\
\text { Unrelated Donors in } \\
\text { Pediatric Patients With } \\
\text { Solid Tumors and } \\
\text { Leukemias }\end{array}$ & $\begin{array}{l}\text { Allogeneic } \\
\text { Bone marrow } \\
\text { NK Cells }\end{array}$ & $\begin{array}{l}\text { Completed } \\
\text { - Has } \\
\text { results }\end{array}$ & $\begin{array}{l}\text { - Leukemia } \\
\text { - Lymphoma }\end{array}$ & $\begin{array}{l}\text { - Biological: } \\
\text { Natural Killer (NK) } \\
\text { Cell Infusion } \\
\text { - Biological: Stem } \\
\text { Cell Infusion } \\
\text { - Pag }\end{array}$ & $\begin{array}{l}\text { Study Type: } \\
\text { Interventional } \\
\text { Phase: } \\
\text { Phase } 1\end{array}$ & $\begin{array}{l}\text { Age: } \\
4 \text { Years to } \\
35 \text { Years } \\
\text { (Child, } \\
\text { Adult) } \\
\text { Sex: } \\
\text { All }\end{array}$ & $\begin{array}{l}\text { - National } \\
\text { Cancer Institute } \\
\text { (NCl) } \\
\text { - National } \\
\text { Institutes of } \\
\text { Health Clinical } \\
\text { Center (CC) }\end{array}$ & $\begin{array}{l}\text { Study Start: } \\
\text { January 29, } \\
2011 \\
\text { Primary } \\
\text { Completion: } \\
\text { June 28, } \\
2018 \\
\text { Last Update } \\
\text { Posted: } \\
\text { August 22, } \\
2019\end{array}$ & $\begin{array}{l}\text { - National Institutes of } \\
\text { Health Clinical Center, } \\
\text { Five of } 9 \text { transplant } \\
\text { recipients experienced } \\
\text { acute graft-versus-host } \\
\text { disease (GVHD) following } \\
\text { aNK-DLI, with grade } 4 \\
\text { GVHD observed in } 3 \\
\text { subjects. }\end{array}$ \\
\hline NCT02716571 & $\begin{array}{l}\text { Recruiting Blood } \\
\text { Donor With Allogeneic } \\
\text { Natural Killer Cell }\end{array}$ & $\begin{array}{l}\text { Allogeneic } \\
\text { natural killer } \\
\text { cell }\end{array}$ & $\begin{array}{l}\text { Completed: } \\
\text { No results } \\
\text { posted }\end{array}$ & - Healthy Volunteers & $\begin{array}{l}\text { - Other: } \\
\text { Leukapheresis or } \\
\text { Plasmapheresis }\end{array}$ & $\begin{array}{l}\text { Study Type: } \\
\text { Interventional } \\
\text { Phase: } \\
\text { Not } \\
\text { Applicable }\end{array}$ & $\begin{array}{l}\text { Enrollment: } \\
90 \\
\text { Age: } \\
20 \text { Years to } \\
60 \text { Years } \\
\text { (Adult) } \\
\text { Sex: } \\
\text { All }\end{array}$ & $\begin{array}{l}\text { - Seoul } \\
\text { National } \\
\text { University } \\
\text { Hospital }\end{array}$ & $\begin{array}{l}\text { Study Start: } \\
\text { March 28, } \\
2016 \\
\text { Primary } \\
\text { Completion: } \\
\text { June 2, } \\
2017 \\
\text { Last Update } \\
\text { Posted: July } \\
\text { 31, } 2017\end{array}$ & $\begin{array}{l}\text { - Seoul National } \\
\text { University Hospital, Seoul, } \\
\text { Korea, Republic of }\end{array}$ \\
\hline NCT00877110 & $\begin{array}{l}\text { Anti-GD2 3F8 } \\
\text { Antibody and } \\
\text { Allogeneic Natural } \\
\text { Killer Cells for High- } \\
\text { Risk Neuroblastoma }\end{array}$ & $\begin{array}{l}\text { Allogeneic NK } \\
\text { Cells from a } \\
\text { family member } \\
\text { who shares } \\
\text { half of the } \\
\text { HLA proteins }\end{array}$ & $\begin{array}{l}\text { Completed: } \\
\text { No results } \\
\text { posted }\end{array}$ & $\begin{array}{l}\text { - Neuroblastoma } \\
\text { - Bone Marrow, } \\
\text { Sympathetic Nervous } \\
\text { System }\end{array}$ & $\begin{array}{l}\text { - Drug: } \\
\text { cyclophosphamide, } \\
\text { vincristine, } \\
\text { topotecan ,allogenei } \\
\text { NK cells \& 3F8 }\end{array}$ & $\begin{array}{l}\text { Study Type: } \\
\text { Interventional } \\
\text { Phase: } \\
\text { Phase } 1\end{array}$ & $\begin{array}{l}\text { Enrollment: } \\
71 \\
\text { Age: } \\
\text { Child, } \\
\text { Adult, } \\
\text { Older Adult } \\
\text { Sex: } \\
\text { All }\end{array}$ & $\begin{array}{l}\text { - Memorial } \\
\text { Sloan Kettering } \\
\text { Cancer Center }\end{array}$ & $\begin{array}{l}\text { Study Start: } \\
\text { April 2, } \\
2009 \\
\text { Primary } \\
\text { Completion: } \\
\text { January 7, } \\
2019 \\
\text { Last Update } \\
\text { Posted: } \\
\text { January 10, } \\
2019\end{array}$ & $\begin{array}{l}\text { - Memorial Sloan } \\
\text { Kettering Cancer Center, } \\
\text { New York, New York, } \\
\text { United States }\end{array}$ \\
\hline
\end{tabular}




\begin{tabular}{|c|c|c|c|c|c|c|c|c|c|c|c|}
\hline & NCT Number & Title & $\begin{array}{l}\text { NK Cell } \\
\text { source }\end{array}$ & Status & Conditions & Interventions & $\begin{array}{l}\text { Clinical trial } \\
\text { phase }\end{array}$ & Population & $\begin{array}{c}\text { Sponsor/ } \\
\text { Collaborators }\end{array}$ & Dates & Locations / Outcome \\
\hline 10 & NCT02301065 & $\begin{array}{l}\text { Analysis of T Cell and } \\
\text { Natural Killer (NK) Cell } \\
\text { in Relation to Viral } \\
\text { Infections in Pediatric } \\
\text { Stem Cell Transplant } \\
\text { Patients and Donors }\end{array}$ & $\begin{array}{l}\text { Blood derived } \\
\text { FCRg-CD56 } \\
+ \text { CD3- NK } \\
\text { cells in } \\
\text { pediatric } \\
\text { allogeneic } \\
\text { HSCT patients } \\
\text { and healthy } \\
\text { donors }\end{array}$ & $\begin{array}{l}\text { Completed: } \\
\text { No results } \\
\text { posted }\end{array}$ & $\begin{array}{l}\text { - Hematologic } \\
\text { Malignancies }\end{array}$ & & $\begin{array}{l}\text { Study Type: } \\
\text { Observational } \\
\text { Phase: }\end{array}$ & $\begin{array}{l}\text { Enrollment: } \\
35 \\
\text { Age: } \\
\text { up to } 21 \\
\text { Years } \\
\text { (Child, } \\
\text { Adult) } \\
\text { Sex: } \\
\text { All }\end{array}$ & $\begin{array}{l}\text { - St. Jude } \\
\text { Children's } \\
\text { Research } \\
\text { Hospital } \\
\text { - Michigan } \\
\text { State University }\end{array}$ & $\begin{array}{l}\text { Study Start: } \\
\text { October 13, } \\
2016 \\
\text { Primary } \\
\text { Completion: } \\
\text { February 6, } \\
2017 \\
\text { Last Update } \\
\text { Posted: July } \\
\text { 17, } 2017\end{array}$ & $\begin{array}{l}\text { - St. Jude Children's } \\
\text { Research Hospital, } \\
\text { Memphis, Tennessee, } \\
\text { United States }\end{array}$ \\
\hline 11 & NCT02845999 & $\begin{array}{l}\text { Allogenic } \\
\text { Immunotherapy Based } \\
\text { on Natural Killer (NK) } \\
\text { Cell Adoptive Transfer } \\
\text { in Metastatic } \\
\text { Gastrointestinal } \\
\text { Carcinoma Treated } \\
\text { With Cetuximab }\end{array}$ & $\begin{array}{l}\text { Haploidentical } \\
\text { Natural Killer } \\
\text { (NK) cells }\end{array}$ & $\begin{array}{l}\text { Completed- } \\
\text { No Results } \\
\text { posted }\end{array}$ & $\begin{array}{l}\text { - Gastrointestinal } \\
\text { Metastatic Cancer }\end{array}$ & $\begin{array}{l}\text { - Biological: } \\
\text { allogenic } \\
\text { immunotherapy } \\
\text { based on Natural } \\
\text { Killer cells adoptive } \\
\text { transfer } \\
\text { - Biological: } \\
\text { cetuximab } \\
\text { - Drug: } \\
\text { Cyclophosphamide } \\
\text { - Drug: } \\
\text { fludarabine } \\
\text { - Drug: } \\
\text { interleukin-2 }\end{array}$ & $\begin{array}{l}\text { Study Type: } \\
\text { Interventional } \\
\text { Phase: Phase } \\
1\end{array}$ & $\begin{array}{l}\text { Enrollment: } \\
9 \\
\text { Age: } \\
18 \text { Years to } \\
65 \text { Years } \\
\text { (Adult, } \\
\text { Older Adult) } \\
\text { Sex: } \\
\text { All }\end{array}$ & $\begin{array}{l}\text { - Centre } \\
\text { Hospitalier } \\
\text { Universitaire de } \\
\text { Besancon } \\
\text { - National } \\
\text { Cancer Institute, } \\
\text { France }\end{array}$ & $\begin{array}{l}\text { Study Start: } \\
\text { November } \\
2009 \\
\text { Primary } \\
\text { Completion: } \\
\text { January } \\
2013 \\
\text { Last Update } \\
\text { Posted: July } \\
\text { 27, } 2016\end{array}$ & $\begin{array}{l}\text { - University hospital of } \\
\text { Besançon, Besançon, } \\
\text { France }\end{array}$ \\
\hline 13 & NCT01181258 & $\begin{array}{l}\text { Penostatin, Rituximab } \\
\text { and Ontak and } \\
\text { Allogeneic Natural } \\
\text { Killer (NK) Cells for } \\
\text { Refractory Lymphoid } \\
\text { Malignancies }\end{array}$ & $\begin{array}{l}\text { Interleukin 2- } \\
\text { activated } \\
\text { Allogeneic } \\
\text { Natural Killer } \\
\text { Cells }\end{array}$ & $\begin{array}{l}\text { Completed- } \\
\text { Has results }\end{array}$ & $\begin{array}{l}\text { - Non-Hodgkin } \\
\text { Lymphoma } \\
\bullet \quad \text { Chronic } \\
\text { Lymphocytic Leukemia }\end{array}$ & $\begin{array}{l}\text { - Drug: Rituximab } \\
\text { - Biological: } \\
\text { Interleukin-2 } \\
\text { - Biological: } \\
\text { Natural killer cells } \\
\text { - Drug: } \\
\text { Cyclophosphamide } \\
\text { - Drug: } \\
\text { Methylprednisolone } \\
\text { - Drug: } \\
\text { Fludarabine }\end{array}$ & $\begin{array}{l}\text { Study Type: } \\
\text { Interventional } \\
\text { Phase: Phase } \\
2\end{array}$ & $\begin{array}{l}\text { Enrollment: } \\
16 \\
\text { Age: } \\
\text { Child, } \\
\text { Adult, } \\
\text { Older Adult } \\
\text { Sex: } \\
\text { All }\end{array}$ & $\begin{array}{l}\text { - Masonic } \\
\text { Cancer Center, } \\
\text { University of } \\
\text { Minnesota }\end{array}$ & $\begin{array}{l}\text { Study Start: } \\
\text { August } \\
2010 \\
\text { Primary } \\
\text { Completion: } \\
\text { September } \\
\text { 2015Study } \\
\text { Completion: } \\
\text { July } 2016 \\
\text { First Posted: } \\
\text { August 13, } \\
2010 \\
\text { Results First } \\
\text { Posted: May } \\
\text { 18, 2017 } \\
\text { Last Update } \\
\text { Posted: } \\
\text { February 6, } \\
2018\end{array}$ & $\begin{array}{l}\text { - Masonic Cancer } \\
\text { Center, University of } \\
\text { Minnesota, Observations } \\
\text { support development of } \\
\text { donor NK cellular } \\
\text { therapies for advanced } \\
\text { NHL as a strategy to } \\
\text { overcome } \\
\text { chemoresistance }\end{array}$ \\
\hline 14 & NCT01105650 & $\begin{array}{l}\text { Allogeneic Natural } \\
\text { Killer (NK) Cells for } \\
\text { Ovarian, Fallopian } \\
\text { Tube, Peritoneal and } \\
\text { Metastatic Breast } \\
\text { Cancer }\end{array}$ & $\begin{array}{l}\text { Allogeneic } \\
\text { donor cells }\end{array}$ & $\begin{array}{l}\text { Completed- } \\
\text { Has results }\end{array}$ & $\begin{array}{l}\text { - } \quad \text { Ovarian Cancer } \\
\text { - } \quad \text { Fallopian Tube } \\
\text { Cancer } \\
\text { - } \quad \text { Primary Peritoneal } \\
\text { Cancer } \\
\text { - } \quad \text { Breast Cancer }\end{array}$ & $\begin{array}{l}\text { - Drug: } \\
\text { Fludarabine } \\
\text { - Drug: } \\
\text { Cyclophosphamide } \\
\text { - Drug: } \\
\text { Cyclosporine }\end{array}$ & $\begin{array}{l}\text { Study Type: } \\
\text { Interventional } \\
\text { Phase: Phase } \\
2\end{array}$ & $\begin{array}{l}\text { Enrollment: } \\
13 \\
\text { Age: } \\
18 \text { Years } \\
\text { and older } \\
\text { (Adult, }\end{array}$ & $\begin{array}{l}\text { - Masonic } \\
\text { Cancer Center, } \\
\text { University of } \\
\text { Minnesota }\end{array}$ & $\begin{array}{l}\text { Study Start: } \\
\text { July } 2010 \\
\text { Primary } \\
\text { Completion: } \\
\text { April } 2014 \\
\text { Last Update }\end{array}$ & $\begin{array}{l}\text { - Masonic Cancer } \\
\text { Center, University of } \\
\text { Minnesota, Some adverse } \\
\text { events reported - not } \\
\text { published }\end{array}$ \\
\hline
\end{tabular}




\begin{tabular}{|c|c|c|c|c|c|c|c|c|c|c|c|}
\hline & NCT Number & Title & $\begin{array}{l}\text { NK Cell } \\
\text { source }\end{array}$ & Status & Conditions & Interventions & $\begin{array}{l}\text { Clinical trial } \\
\text { phase }\end{array}$ & Population & $\begin{array}{l}\text { Sponsor/ } \\
\text { Collaborators }\end{array}$ & Dates & Locations / Outcome \\
\hline & & & & & & $\begin{array}{l}\text { - Biological: } \\
\text { Natural killer cells } \\
\text { - Drug: IL-2 } \\
\text { - Drug: } \\
\text { Methylprednisolone } \\
\text { - Drug: } \\
\text { Interleukin-2 }\end{array}$ & & $\begin{array}{l}\text { Older Adult) } \\
\text { Sex: } \\
\text { Female }\end{array}$ & & $\begin{array}{l}\text { Posted: } \\
\text { December } \\
\text { 28, } 2017\end{array}$ & \\
\hline 15 & NCT00586703 & $\begin{array}{l}\text { Safety Trial of NK Cell } \\
\text { DLI 3-5/6 Family } \\
\text { Member Following } \\
\text { Nonmyeloablative } \\
\text { ASCT }\end{array}$ & $\begin{array}{l}\text { CD56-NK } \\
\text { cells from } \\
\text { mismatched } \\
\text { donors }\end{array}$ & $\begin{array}{l}\text { Completed- } \\
\text { Has results }\end{array}$ & - Lymphoma & $\begin{array}{l}\text { - Device: NK- } \\
\text { CD56 }\end{array}$ & $\begin{array}{l}\text { Study Type: } \\
\text { Interventional } \\
\text { Phase: } \\
\text { Phase } 1\end{array}$ & $\begin{array}{l}\text { Enrollment: } \\
21 \\
\text { Age: } \\
18 \text { Years } \\
\text { and older } \\
\text { (Adult, } \\
\text { Older Adult) } \\
\text { Sex: } \\
\text { All }\end{array}$ & $\begin{array}{l}\text { - David Rizzieri, } \\
\text { MD • Duke } \\
\text { University }\end{array}$ & $\begin{array}{l}\text { Study Start: } \\
\text { April } 2005 \\
\text { Primary } \\
\text { Completion: } \\
\text { April } 2013 \\
\text { Last Update } \\
\text { Posted: } \\
\text { June 12, } \\
2014\end{array}$ & $\begin{array}{l}\text { Duke University Health } \\
\text { Systems" A 1-step, high- } \\
\text { yield process is feasible, } \\
\text { and results in high doses } \\
\text { of NK cells infused with } \\
\text { little toxicity. NK cell- } \\
\text { enriched DLIs result in } \\
\text { improved immune } \\
\text { recovery and outcomes } \\
\text { for some }\end{array}$ \\
\hline 16 & NCT02118285 & $\begin{array}{l}\text { Intraperitoneal Natural } \\
\text { Killer Cells and } \\
\text { INCB024360 for } \\
\text { Recurrent Ovarian, } \\
\text { Fallopian Tube, and } \\
\text { Primary Peritoneal } \\
\text { Cancer }\end{array}$ & $\begin{array}{l}\text { haploidentical } \\
\text { donor NK } \\
\text { cells and IL-2 }\end{array}$ & $\begin{array}{l}\text { Completed- } \\
\text { No results } \\
\text { posted }\end{array}$ & $\begin{array}{l}\text { - Ovarian Cancer } \\
\text { - Fallopian Tube } \\
\text { Carcinoma } \\
\text { - Primary Peritoneal } \\
\text { Carcinoma }\end{array}$ & $\begin{array}{l}\text { - Drug: } \\
\text { Fludarabine } \\
\text { - Drug: } \\
\text { Cyclophosphamide } \\
\text { - Biological: NK } \\
\text { cells } \\
\text { - Biological: IL-2 } \\
\text { - Drug: } \\
\text { INCB024360 }\end{array}$ & $\begin{array}{l}\text { Study Type: } \\
\text { Interventional } \\
\text { Phase: } \\
\text { Phase } 1\end{array}$ & $\begin{array}{l}\text { Enrollment: } \\
2 \\
\text { Age: } \\
8 \text { Years } \\
\text { and older } \\
\text { (Adult, } \\
\text { Older Adult) } \\
\text { Sex: } \\
\text { Female }\end{array}$ & $\begin{array}{l}\text { - Masonic } \\
\text { Cancer Center, } \\
\text { University of } \\
\text { Minnesota } \\
\text { - Incyte } \\
\text { Corporation }\end{array}$ & $\begin{array}{l}\text { Study Start: } \\
\text { July 28, } \\
2014 \\
\text { Last Update } \\
\text { Posted: } \\
\text { December } \\
\text { 5, } 2017\end{array}$ & $\begin{array}{l}\text { - University of } \\
\text { Minnesota Masonic } \\
\text { Cancer Center, } \\
\text { Minneapolis, Minnesota, } \\
\text { United States }\end{array}$ \\
\hline 18 & NCT00526292 & $\begin{array}{l}\text { Chemotherapy and a } \\
\text { Donor Natural Killer } \\
\text { Cell Infusion in Treating } \\
\text { Patients With } \\
\text { Relapsed or Persistent } \\
\text { Leukemia or } \\
\text { Myelodysplastic } \\
\text { Syndrome After a } \\
\text { Donor Stem Cell } \\
\text { Transplant }\end{array}$ & $\begin{array}{l}\text { Allogeneic NK } \\
\text { Cells from a } \\
\text { family member } \\
\text { who shares } \\
\text { half of the } \\
\text { HLA proteins }\end{array}$ & $\begin{array}{l}\text { Completed:- } \\
\text { Has results }\end{array}$ & $\begin{array}{l}\text { - Leukemia } \\
\text { - Myelodysplastic } \\
\text { Syndromes }\end{array}$ & $\begin{array}{l}\text { - Biological: } \\
\text { natural killer cell } \\
\text { therapy } \\
\text { - Drug: } \\
\text { cyclophosphamide } \\
\text { - Drug: } \\
\text { fludarabine }\end{array}$ & $\begin{array}{l}\text { Study Type: } \\
\text { Interventional } \\
\text { Phase: } \\
\text { Phase } 2\end{array}$ & $\begin{array}{l}\text { Enrollment: } \\
12 \\
\text { Age: } \\
\text { up to } 120 \\
\text { Years } \\
\text { (Child, } \\
\text { Adult, } \\
\text { Older Adult) } \\
\text { Sex: } \\
\text { All }\end{array}$ & $\begin{array}{l}\text { - Memorial } \\
\text { Sloan Kettering } \\
\text { Cancer Center } \\
\text { - National } \\
\text { Cancer Institute } \\
\text { (NCl) }\end{array}$ & $\begin{array}{l}\text { Study Start: } \\
\text { August } \\
2007 \\
\text { Primary } \\
\text { Completion: } \\
\text { July } 2015 \\
\text { Last Update } \\
\text { Posted: } \\
\text { February 12, } \\
2016\end{array}$ & $\begin{array}{l}\text { - Memorial Sloan } \\
\text { Kettering Cancer Center, } \\
\text { New Yor: Results not } \\
\text { conclusive as } 4 / 6 \text { patients } \\
\text { showed some adverse } \\
\text { events }\end{array}$ \\
\hline 19 & NCT02854839 & $\begin{array}{l}\text { A Study of MG4101 } \\
\text { (Allogeneic Natural } \\
\text { Killer Cell) for } \\
\text { Intermediate-stage of } \\
\text { Hepatocellular } \\
\text { Carcinoma }\end{array}$ & $\begin{array}{l}\text { allogeneic } \\
\text { Natural killer } \\
\text { cells }\end{array}$ & $\begin{array}{l}\text { Completed } \\
\text { No results } \\
\text { posted }\end{array}$ & $\begin{array}{l}\text { - Hepatocellular } \\
\text { Carcinoma }\end{array}$ & $\begin{array}{l}\text { - Biological: } \\
\text { MG4101 }\end{array}$ & $\begin{array}{l}\text { Study Type: } \\
\text { Interventional } \\
\text { Phase: } \\
\text { Phase } 2\end{array}$ & $\begin{array}{l}\text { Enrollment: } \\
78 \\
\text { Age: } \\
18 \text { Years to } \\
80 \text { Years } \\
\text { (Adult, } \\
\text { Older Adult) } \\
\text { Sex: } \\
\text { All }\end{array}$ & $\begin{array}{l}\text { - Green Cross } \\
\text { LabCell } \\
\text { Corporation }\end{array}$ & $\begin{array}{l}\text { Study Start: } \\
\text { November } \\
28,2016 \\
\text { Primary } \\
\text { Completion: } \\
\text { September } \\
27,2018 \\
\text { Last Update } \\
\text { Posted: } \\
\text { September } \\
\text { 26, } 2019\end{array}$ & $\begin{array}{l}\text { - Seoul National } \\
\text { University Hospital, Seoul, } \\
\text { Korea, Republic of } \\
\text { - Seoul Asan Medical } \\
\text { center, Seoul, Korea, } \\
\text { Republic of } \bullet \text { Samsung } \\
\text { Medical Center, Seoul, } \\
\text { Korea, Republic of and } \\
\text { others }\end{array}$ \\
\hline
\end{tabular}




\section{NCT Number}

Title

NK Cell

Status

Conditions

Interventions

Clinical trial Population

Sponsor/

20 NCT01386619 NK DLI in Patients HLA

After Human
Leukocyte Antigen

Leukocyte Antigen
(HLA)- Haploidentica

$(\mathrm{H} L A)-$ Haploidentica
Hematopoietic Stem

$\begin{array}{ll}\text { HLA } & \text { Completed } \\ \text { haploidentical } & \text { No results }\end{array}$

- Leukemia, Myeloid,

Biological: CD3-

University

Locations / Outcome

-CD3-

posted

Acute - Precur

depleted/CD56+ Study Type: E

Leukemia- Lymphoma

Interventional 15

Enrollment:

Hospital, Basel

- Universitätsklinikum

coso

- Myelodysplastic

killer cells collected - Phase

Age:

Switzerland

January

Frankfurt, Germany

Cell Transplantation selected

Syndromes

products

- Phase 2

Adult,

natural killer

- Neuroblastom

Older Adult

cells collected

- Rhabdomyosarcoma

Sex:

Primary

- University Hospital,

from

All

March 2011

Last Update

Posted:

September

15, 2015

21 products

Cell Transplant in Completed

$\begin{array}{ll}\text { Treating Patients With } & \text { Blood derived cells and }\end{array}$

Relapsed Acute also stem

Myeloid Leukemia cells from the

same

allogeneic

dono

- Biological:
aldesleukin
- Biological:
therapeutic
allogeneic
lymphocytes
- Drug:
cyclophosphamide
- Drug:
fludarabine
phosphate
- Procedure: in
vitro treated
peripheral blood
stem cell
transplantation

Study Type: Enrollment:

Interventional

Phase: Age:

Age:

- Masonic

Study Start: - Masonic Cancer

March 2005 Center, Minneapolis, :

Primary Supports the need to

Completion: optimize the in vivo

and older June 2008 cytokine milieu where

(Child,

Last Update adoptively transferred NK

Posted: cells compete with other

$\begin{array}{lll}\text { Adult, } & \text { Posted: } & \text { cells compete with other } \\ \text { Older Adult) } & \text { December } & \text { lymphocytes to improve } \\ \text { Sex: } & 28,2017 & \text { clinical efficacy in patients }\end{array}$

Sex:

with refractory AML 
A

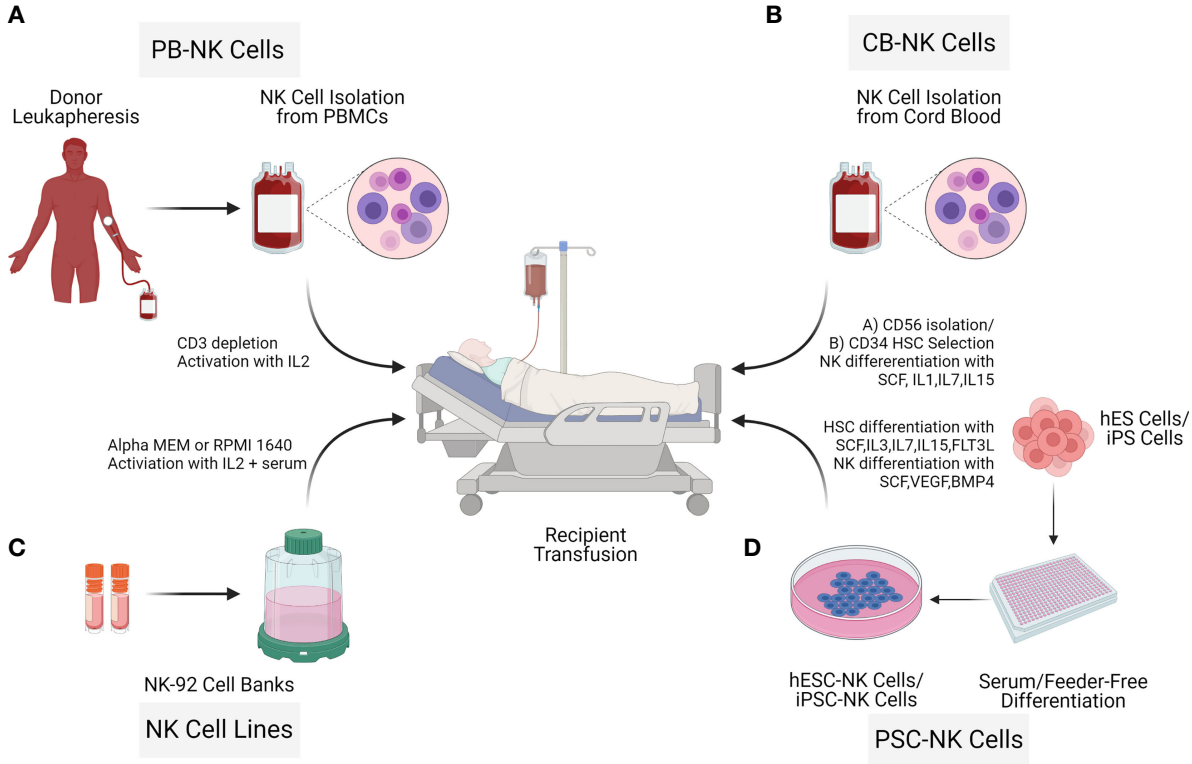

FIGURE 3 | Sources of Natural killer cells for immunotherapy. NK cells for cell therapy applications can originate from different sources: Peripheral blood NK cells (PB NK cells) (A), allogeneic umbilical cord blood NK cells (CB-NK Cells) (B), NK cell cancer cell lines (NK-92) (C), human embryonic stem cells (hESC) and inducible pluripotent stem cells (iPSCs) (D). Advantages and limitations with the different NK cell sources vary as described in the NK cell isolation section.

\section{Umbilical Cord Blood}

The umbilical cord is an abundant source of cytotoxic $\mathrm{CD} 56^{\mathrm{pos}} \mathrm{CD} 16^{\mathrm{pos}} \mathrm{NK}$ cells, with high lytic potential of cancer cells (27). UCB-NK cells are isolated from cord blood after birth, via venipuncture of the umbilical cord, and purification by density gradient centrifugation (28). Alternatively, CD34 hematopoietic stem cells can be isolated from UCB and differentiated to NK cells $(19,29)$. NK cells generated from CD34 cells from HLA matched umbilical cord blood units showed good tolerance, no GVHD or toxicity (30). UCB is a readily available source with the potential to manufacture multiple doses from a single frozen vial of NK cells isolated from a healthy donor $(21,31)$. In addition, UCB NK cells are of a younger and more proliferative phenotype relative to $\mathrm{PB}$ NK cells $(32,33)$.

\section{Peripheral Blood}

Peripheral blood contains NK cells and is a reliable source of CD34 progenitor cells from individuals undergoing GCS-F mobilization (34). Isolating large numbers of PB NK cells and hematopoietic stem cells is difficult as the percentage derived from leukapheresis can be low and highly variable $(22,35,36)$. Further, cryopreservation of PB NK cells lowers the cytotoxic ability $(35,37)$. Allogeneic NK cells can be isolated from PBMCs by either CD3/CD19 depletion (38) or CD3 depletion and subsequent CD56 enrichment (39). The second round of purification based on CD3 depletion can also be implemented post-expansion (39) to increase NK cell purity. An evaluation of 94 samples with CD3/CD19 depletion and 13 samples with CD3 depletion/CD56 enrichments for NK cell isolations in support of 8 clinical trials demonstrated limitations and benefits with $\mathrm{NK}$ cell isolation strategies (34). CD3/CD19 depletion resulted in a mean NK cell recovery of $74 \%$ and viability of $96 \%$. However, CD3 depletion/CD56 enrichment resulted in a high NK cell purity (90\%), with 5\% CD14 monocytes (38).

\section{iPSC or hESC Derived NK Cells}

Pluripotent stem cells (iPSC or hESC) are an unlimited source for the derivation of human NK cells for therapy. NK cells derived from iPSC/hESC result in a homogenous population, which can be expanded on a large scale and can be genetically modified (40). NK cells are generated from different iPSC cell lines (41-43) on stromal feeders using IL-3, IL-7, IL-5, Stem cell factor (SCF), fms-like tyrosine kinase receptor-3 ligand (FLT3L) (24). NK cells derived this way are homogenous and express CD56, KIR, CD16, NKp44, NKp46, and are capable of killing tumor cells (24). Similar to iPSCs, hESCs can also be differentiated to NK cells based on stromal cell-mediated differentiation, involving CD34+CD45+ cell sorting and $\mathrm{NK}$ cell differentiation with IL-3, IL-5, IL-7, fms-like tyrosine kinase receptor 3 ligand (FLT3L), and Stem cell factor (SCF) (26).

Recently a stromal-free process for iPSC NK cell generation has been established based on embryoid bodies (EB) as selfstromal cells are formed inside the EB (40). Feeder-dependent hESC/iPSC was adapted to a feeder independent system before EB generation (44). To generate EBs, hESC/iPSC are seeded in APEL media containing SCF, BMP4, VEGF, Rocki (rho kinase inhibitor). In the second and final step, NK cells are generated by transferring EBs to gelatin-coated wells containing $\mathrm{NK}$ cell differentiation media with IL-3, SCF, IL-7, and IL-15. After 
four weeks of culture, differentiated NK cells stained positive for CD45 and CD56 markers were harvested (40).

\section{NK Cancer Cell Lines}

Among the available NK cancer cell lines, only NK-92 cell line has shown antitumor activity in a variety of tumors and has worked well in pre-clinical studies $(21,45)$. Furthermore, NK-92 cancer cell line has received FDA approval for clinical phase patient trials $(46,47)$. The NK-92 cancer cell line is well characterized and robust clinical protocols are available for cGMP manufacturing (48). These cells can be genetically engineered, but with a variable efficiency of $4 \%-95 \%$ (49) and expanded to substantial numbers. However, NK-92 cancer cell line requires irradiation prior to infusion, as it is cytogenetically abnormal. Select advantages and disadvantages with NK cells derived from different tissue sources are shown in Table 2.

\section{NK CELL EXPANSION FOR THE CREATION OF ALLOGENEIC DOSES}

Regardless of how the NK cells are sourced, every method of NK cell expansion can be classified as either a feeder-cell-based system or a feeder-free system. A multitude of cells and cell lines are used as feeders to stimulate allogeneic NK cell expansion. K562 leukemia cells have been successfully used in this regard for several decades (50) and are the most used and well-characterized example. Other examples including EBV transformed lymphoblastoid (EBV-LCL) (51), HEK293 (52), autologous irradiated PBMCs (53), Jurkat cells (54), the Wilms tumor cell line, HFWT (la5), RPMI1866 (55), MM170 (56), and Daudi (57) have also been applied with varying degrees of success. Strategies to prime and propagate NK cells using EBV-transformed lymphoblastoid cells and irradiated PBMCs continue to show promise, but protocols employing K562 cells remain superior in terms of both the magnitude and speed of expansion. Still, many groups attempt to improve the outcome even more by supplementing the culture with antibodies, such as OKT-3 $(58,59)$ and other cyto-stimulants, such as PHA, ionomycin (53), and concanavalin A (60). One group has even claimed an extremely robust average of 50,000-fold expansion in 21 days (about 3 weeks) using a modified K562 line that expresses membrane-bound IL-21 (61). A potential pitfall of employing feeder cells is that they are associated with a multitude of regulatory concerns. These cells must be stringently qualified using cumbersome assays and viral testing to ensure that they are free of microbial contaminants, such as mycoplasma (62). Moreover, additional actions need to be taken to ensure that the final product is free from the feeder cells. This has encouraged researchers to develop and employ several feeder-free systems in the cultivation of NK cells.

To date, there has been a clear trade-off in that feeder-free systems alleviate many regulatory concerns but result in much lower yields. Several cell-free methods can be explored to activate and stimulate NK cells, including cytokines, and antibodies. Cytokines represent the most widely studied and earliest feederfree method for activating NK cells. IL-2 is the most potent NK cell stimulant and elicits immunostimulatory signaling, increases cytokine release (63), promotes cell motility (63), and enhances cytotoxicity (64). More recently, many alternative immunogenic cytokines have garnered attention for NK stimulation, including interleukins-15, -21, -12, -18, and -27. Much like IL-2, IL-15 stimulates NK cell proliferation, immunostimulatory receptor expression, and cytotoxicity $(65,66)$, which makes it a great candidate to be used as an NK stimulant in a stand-alone fashion. In addition, it boasts several benefits over IL-2. MarksKonczalik and colleagues reported that IL-15 inhibited activationinduced cell death that results from continuous IL-2 stimulation (67)and unlike IL-2, IL-15 does not induce activation and proliferation of Tregs (68), which results in peripheral tolerance and potentially leads to a more robust anti-tumor response. However, there is a tradeoff, research conducted by Felices et al. recently demonstrated that sustained IL-15 signaling results in exhausted NK cells and a loss of in vitro and in vivo efficacy (69). Several groups have tried to stimulate NK cells with lower doses of IL-2 or IL-15 in combination with some of the other cytokines or they have developed cytokine schedules to alleviate some of the drawbacks associated with persistent stimulation with the one cytokine over the entire expansion protocol (70). IL-21 alone is not sufficient to stimulate significant NK-cell expansion $(71,72)$, however, there is a synergistic proliferative effect when IL-21 is

TABLE 2 | Advantages and drawbacks of NK Cells from different sources.

\begin{tabular}{|c|c|c|}
\hline The Source of NK Cells & Advantages & Drawbacks \\
\hline \multirow[t]{3}{*}{ Peripheral Blood derived NKs (PB-NKs) } & High expression of CD16+ & Low number of NK Cells in PB \\
\hline & Highly cytotoxic & Lower or no expression of CXCR4 \\
\hline & Expression of CD57, a marker of terminal differentiation of NK Cells & \\
\hline \multirow[t]{3}{*}{ NK-92 cancer cell line } & Cell line product -easy to obtain & Need for irradiation before injection \\
\hline & Clinically approved & Tumorigenesis potential \\
\hline & CD16 negative & Safety concerns \\
\hline \multirow[t]{3}{*}{ Umbilical Cord Blood derived NKs (UCB-NKs) } & High expression of $\mathrm{CXCR} 4$ & Reduced cytotoxicity (against K562 tumor cell line) \\
\hline & Minimize GvHD & Low numbers \\
\hline & Ready reconstitution after transplant & Immaturity of NK cells \\
\hline \multirow[t]{2}{*}{ Placental blood derived NKs ( $\mathrm{p}-\mathrm{NK}$ s) } & Placenta rich source for NK cells & Low cytolytic activity \\
\hline & Easily, readily available & \\
\hline \multirow[t]{3}{*}{ iPSC derived NKs (iNKs) } & Resource to generate unlimited numbers relevant for therapy & Complex differentiation steps \\
\hline & Minimal immune rejection & Clinical effectiveness still to be proven \\
\hline & & Safety issues \\
\hline
\end{tabular}


combined with other immunostimulatory cytokines like IL-2 and IL-15 (71, 72). Furthermore, the addition of IL-21 to NK cell culture has been associated with increased immunostimulatory cytokine production (73) and upregulation of perforin and granzyme A and B (74), leading to enhanced NK cell cytotoxicity $(75,76)$. IL-12, IL-18, and IL-27 are slightly less characterized but have also displayed the ability to positively contribute to NK cell expansion, especially when used in conjunction with the IL-2 or IL-15. Research demonstrates that IL-12 can have a synergistic effect with IL-2, which results in enhanced NK cell cytokine secretion, proliferation, and cytotoxic capacity $(77,78)$. IL-18 and IL-27 have recently been combined with IL-15 to boost NK cell fold expansion (79). Another advantage of combining the cytokines can result in a lower dose of the individual cytokines, which can lead to a higher percentage of memory NK cells (19). The combination of IL-12, IL-15, and IL-18 drives preferential expansion of memory-like NK cells, which exhibit heightened responses when they encounter tumor cells (79-81) and longer lifespans following engraftment (79-81). An additional benefit of these cells is an increased capacity to produce immunostimulatory cytokines upon secondary challenge. This memory response is an intrinsic quality that is passed on to all cellular progeny (79-81).

Apart from these most common feeder-cell and feeder-free cytokine systems, several groups have moved towards strategies that are a hybrid of the two. Several groups have engineered feeder cells that express immunostimulatory signaling molecules, such as 41BB, IL-15 $(82,83)$, and IL-21 $(63,84-86)$ on their cell surfaces. These strategies have resulted in highly cytotoxic NK cells that display both extremely high proliferative capacities (up 50,000-fold expansion) (61), extended survival, and the ability to secrete immunogenic cytokines, leading many groups to adopt these methods into their clinical protocols. This approach has recently been taken one step further to avoid safety concerns by stimulating NK cells with K562-mb21-41BBL cell lysates (87).

Most of the experiments and trials discussed in this review have utilized small-scale, open methods for NK cell activation and expansion, such as flasks and G-Rex vessels. However, these methods are hampered by logistical hurdles, inconsistencies, and safety concerns. To reach the desired cell numbers for allogeneic manufacturing and clear all regulatory and safety hurdles associated with drug approval, it will be necessary to develop closed, and automated systems with large-scale capabilities. Hence, clinical scale NK cell manufacturing development suitable for effective allogeneic therapy production is a priority. Several options have been explored, including a G-Rex-based method that was developed under good manufacturing practice (GMP) conditions and required little to no manual intervention for the 8- to 10-day expansion and yielded 19 billion functional NK cells (88). Another example of static culture is the use of large, gas-permeable culture bags, which were successfully applied in combination with feeder cells, antibodies, and cytokines to yield an NK cell fold expansion of 15,000 (89). A more recent trend for achieving clinical scale NK cell expansion has been the use of bioreactors. In addition to large cell capacity, these devices are highly adaptable for closed and automated manufacturing processes (Figure 4). Robust NK cell expansion with the Xuri Cell Expansion System W25 (Cytiva) has been demonstrated by several groups (90-92). The most common approach is to expand the isolated NK cells in static culture before transferring them to rocking bioreactors, which effectively nourish high cell densities (90-92). These workflows were able to generate 50 billion highly cytotoxic NK cells (91). Stirred tanks are another type of dynamic culture bioreactor that has gained favor in the NK cell therapy community. Pierson and colleagues first demonstrated that the cultivation of NK cells in a $750 \mathrm{ml}$ stirred tank significantly outperforms that in a comparable static vessel (93). Moreover, it was recently shown that NK cell propagation in $2 \mathrm{~L}$ stirred tanks scaled up exceptionally well to 50L stir tanks (94) making this platform an excellent fit for allogeneic manufacturing workflows. Aside from the well-known wave motion reactors and stirred tank reactors, there has also been success using lesser-characterized reactors, such as the ZRP Bioreactor 50M, which was able to grow massive amounts of highly pure and functional NK cells (95).

\section{NK CELL THERAPY PACKAGING AND RELEASE TESTING}

Once the desired expansion is achieved, a major challenge is the downstream processing of these cells and preparing the allogeneic doses. Manufacturing and storing these "off-the-shelf" doses remotely, requires cryopreservation, which is often problematic in the case of NK cells. In addition to a loss in cell viability, it is common to see a significant drop in cytotoxicity after thawing. This functional loss routinely corresponds to a reduction in the expression of CD16 on NK cell surfaces (63). However, many groups are attempting to mitigate these issues with different strategies. A few more promising examples are to expose thawed cells to IL-2 immediately, thereby restoring their cytotoxic capacity (60), using twice as many cells in the dose to compensate for the reduced function per cell (96), and inoculating the NK cells immediately after thawing them $(37,96)$. A separate, but related concern, is a 6-fold decrease in motile NK cells following cryopreservation (37). Efforts to develop effective cryopreservation solutions that preserve NK cell numbers and functionality are currently a priority to carry this field forward.

Beyond viability and cytotoxicity issues following the cryopreservation and recovery cycle, there is a multitude of other criteria that should be considered before confidently releasing the NK cells for administration as a therapeutic dose. Safety is the overarching theme for most of these considerations. Several of these requirements are focused on confirming that there are no undesirable trespassers in the dose, such as endotoxins, mycoplasma, bacteria, or feeder cells if they were used for expansion. Confirmation that the dose consists of the desired cellular population is also highly important in preventing the onset of adverse effects that these cellular contaminants can cause. This can be done by setting a minimum requirement for the percent of $\mathrm{CD} 56^{\mathrm{pos}} / \mathrm{CD} 3^{\text {neg }}$ cells and a maximum allowed 


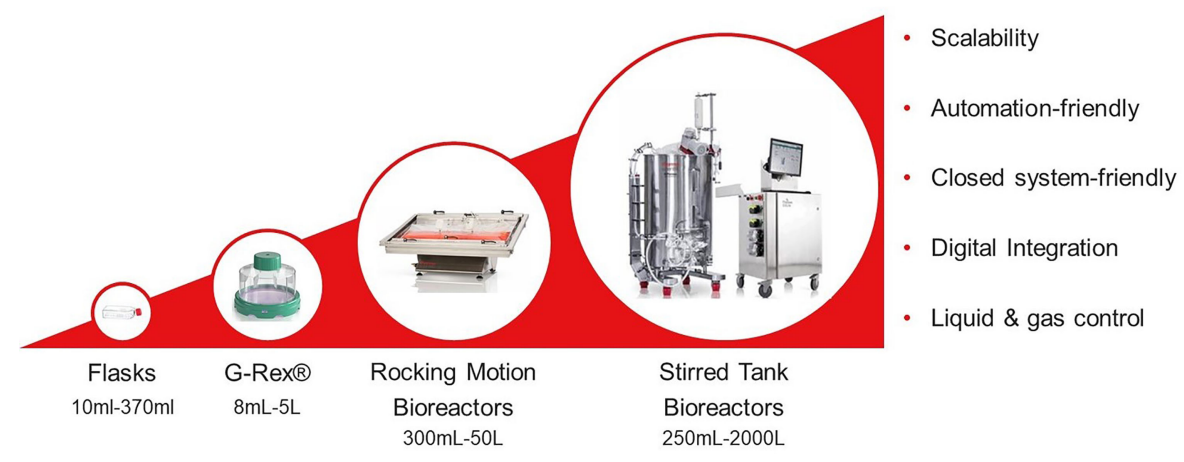

FIGURE 4 | Bioreactors offer several advantages to the clinical manufacturing of cell therapies. The shift from static vessels on the left toward dynamic bioreactors on the right allows for several process improvements, such as scalability, automated and closed operation, digital integration, and intimate control of liquids. These capabilities result in increased safety and consistency, reduced labor requirement and cost, and improved quality of cellular output.

amount of $\mathrm{CD} 3^{\text {pos }} \mathrm{T}$ cells, $\mathrm{CD} 19^{\text {pos }} \mathrm{B}$ cells, and $\mathrm{CD} 14^{\text {pos }}$ monocytes that can safely be released in a dose. These are the key regulatory principles that agencies across different geographical locations will require for cell therapies. Several additional ideas could be incorporated to further ensure therapeutic efficacy. An example of this could be flow cytometric characterization of activating receptors, such as NCRs, NKG2D, NKG2C, NKG2E, 2B4 and the inhibitory receptors NKG2A and KIRs. In addition, indicators of cytotoxic capabilities, CD16 and CD25, markers of differentiation status, CD62L, CD45, HLA-DR, CD69, and CD57, and functional analysis of IFN $\gamma$ or TGF- $\beta$ can be included (20) (Figure 5). It may also be beneficial to modify the cellular requirement based on the characteristics of the disease state. The tumors and surrounding microenvironments pose significant obstacles that are directly opposed to the proper function of adoptive cell therapies, such as NK cell therapies (97). While many of the escape mechanisms are identified, there is often no way to identify which ones a particular tumor is employing. Thus, understanding the individual challenges associated with each tumor through a standardized molecular imprint could go a long way in cultivating the most effective cell therapy or combination therapy.

\section{CAR-NK ENGINEERING}

When NK cells are engineered with a tumor-specific chimeric antigen receptor (CAR), superior NK cell elicited cytotoxicity and improved cell infiltration into the tumor microenvironment are noticed. Genetic modification of NK cells by transducing with CAR receptors directed against tumor specific antigens may enhance both NK cell tumor specificity and NK cell persistence. CARs are engineered receptor proteins that recognize a target antigen on tumor cells and are successfully used in T cell therapy for lymphoid leukemias. Most of the CAR-T trials are restricted to autologous therapies, which are cumbersome, although strikingly efficient in targeted tumor cell killing (98). The development of allogeneic CAR-T cells is challenging, as these treatments must be specifically tailored to avoid graft versus host diseases (GVHD) and elimination by the host immune system (99). In contrast, several advantages are recognized with CARNK cell therapy over CAR-T cell therapy clinical approaches. First, there are less side effects such as low/no GVHD (100), cytokine release syndrome (101) and neurotoxicity (102). Second, CAR-NK cells can also eliminate tumor cells efficiently in a CAR-independent manner through their stimulatory and inhibitory receptors and CD16-mediated ADCC (103). Therefore, several researchers are exploring different approaches to genetically engineer NK cells with CARs to augment the efficiency of NK cells to kill tumors (104).

NK cells are successfully engineered to express CARs against several tumor-specific antigen targets and are shown to be efficient for in vitro and in vivo killing of tumor cells in experimental investigational studies. Human iPSC-derived NK cells engineered with specific CAR constructs demonstrated significantly enhanced targeted anti-tumor activity in an ovarian cancer xenograft model (105). Although autologous NK cells can be generated in vitro, they have limited efficiency against own patient's tumor cells. There are currently 72 clinical trials using CAR-NK cell lines and 35 primary CAR-NK preclinical studies based on PubMed and Global data (www. carnkreview.com) targeting different tumors (106). However, only 5 studies are ongoing in phase I \& II clinical trials at www.clincaltrials.gov (Table 3). CAR constructs for NK cells consist of three domains: an extracellular antigen recognition domain, a transmembrane domain, and an intracellular cytoplasmic signaling domain (Figure 6). The ectodomain contains a single-chain variable fragment $(\mathrm{scFv})$ derived from an antibody recognizing the tumor antigen. The transmembrane domain anchors the CAR structure to the effector cell membrane. CAR recognition of specific antigen triggers intracellular activation domain that results in the killing of the target cells. From the limited number of CAR-NK trials so far, no significant adverse events are noted, and the CAR-NKs showed robust 


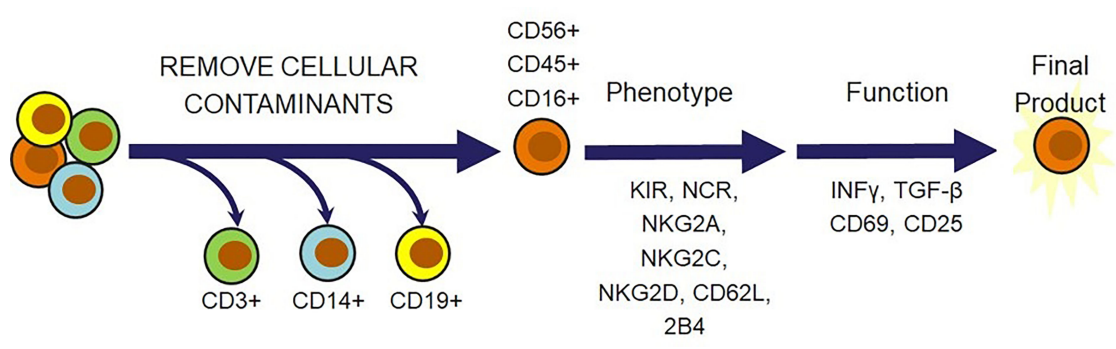

FIGURE 5 | Natural killer cell-specific strategies for NK cell therapy release criteria. In addition to verifying that cell therapies are free from endotoxins, mycoplasma, bacteria, and feeder cells, there is a multitude of cell markers that can be selected to ensure that the therapeutic population possesses desired phenotypic and functional qualities. T cells, monocytes, and B cells must be removed for safety. Receptors and cytokines can then be evaluated to confirm that the outgoing cell population is responsive, cytotoxic, and safe.

cytolytic activity. In the CAR-NK trials that fit the allogeneic and off-the-shelf approach, CAR-NK cells from a single healthy donor were expanded in cell culture for appropriate dosing. The infused CAR-NKs persisted and expanded at a low level, based on PCR results, for a year within the tumor microenvironment in an ablative conditioning regimen. Most engineered CAR-NK cells are directed against blood-related malignancies, such as CD19 for B cell lymphomas, CD22 for refractory B-cell lymphomas and solid tumors, NKG2D-ligand for pancreatic cancers, and CD33 and ROBO1 specific BiCARNK/T for malignant and metastatic solid tumors (107). Barriers to a successful implementation of CAR-NK in solid tumors are recently reviewed, including off-tumor effects, impaired antigen recognition, poor cell trafficking, harsh tumor environment, and immune evasion (108).

\section{DELIVERY SYSTEMS TO ENGINEER NK CELLS}

A critical aspect of CAR-NK generation is the introduction of genetic elements into NK cells, referred to as CAR-NK engineering. Once the genetic element is introduced into NK cells, the subsequent expansion of the CAR-NK cells with the cytotoxic killing of the target tumor cell will be another important consideration. The introduction of genetic material into NK cells is carried out using either viral vectors (retrovirus, lentivirus, and Adeno associated virus) or non-viral methods (mRNA and DNA). Examples of the viral and non-viral vector delivery systems with select pros and cons are shown in Table 4 and Figure 7.

\section{Retroviral Vector Systems}

Recent studies from the Rezvani laboratory at MDACC used retroviral vectors to deliver anti-CD19 CAR into NK cells along with IL-15 and inducible caspase 9. The CAR NK cells were used to treat CD19 positive tumors; 7 of 11 patients (64\%) had a complete response ( 4 of 5 patients with CLL and 4 of 6 with nonHodgkin's lymphoma). All 8 patients had an objective response (73\%) at 13.8 month follow-up (109). Gene transfer did not change the function or phenotype of NK cells, nor did it change the proliferative or cytotoxic ability post engineering. Another recent study used retroviral vector systems that ectopically expressed iC9/CAR.19/IL15 to generate CAR-CD19-NK cells from cord blood that persisted for a long time in the tumor microenvironment $(110,111)$. In both studies, the retroviral vector ectopically produced IL15 that is crucial for NK cell survival and conditionally expressed a caspase 9 (iC9)- an inducible suicide gene that could be activated to shut off the system by eliminating transduced cells when needed. Though retroviral vector systems have high transfection efficiency, the cDNA can integrate into the NK cell genome causing insertional mutagenesis and sometimes an induction of immune response (112).

\section{Lentiviral Vector Systems}

Lentiviral transduction is the preferred choice to modify NK cells. The lentiviral method allows transduction of primary and non-activated NK cells, and unlike the retroviral vector system, does not require dividing cells (113). Single lentiviral transduction usually results in lower transduction efficiencies, PB NK $(<10 \%)$ or CB NK (<30\%) (114). In Japan, a study led by Dr. Ueda used a lentiviral system to express CAR-NK-GPC3 for solid tumors of hepatocellular carcinoma (HCC) and ovarian cancers that are treated in in vivo animal models with good success (115). Recent studies have improved the efficiencies of lentiviral delivery, by using statins to upregulate the low-density lipoprotein (LDL) receptor on NK cells enhancing the transduction efficiency by 30-50\% (116).

Pseudotyped lentiviral particles are glycoproteins derived from other enveloped viruses that enable the tropism of the lentiviral. The ability to generate CAR-NK cells depends on the envelope protein lentivirals express. Vesicular stomatitis virus $G$ glycoprotein (VSV-G) pseudotype particles showed the highest transduction efficiency of primary NK cells compared to retroviral vectors (117). Feline endogenous retrovirus envelope protein RD114-TR was similar to VSV-G pseudotype particles for primary human NK cells (118). Further, a Baboon envelope pseudotyped lentiviral vector BaEV-LV was significantly better than both the RD-114-TR and VSV-G pseudotyped lentiviral vector (119). Choosing which LV pseudotypes VSV-G versus RD114-TR versus BaEV-LV has the best transduction efficiency 
TABLE 3 | On-going CAR-NK Clinical Trials.

\begin{tabular}{|c|c|c|c|c|c|c|c|c|c|c|}
\hline & NCT Number & Title & Status & Conditions & Source of NK Cells & Interventions & $\begin{array}{l}\text { Clinical trial } \\
\text { phase }\end{array}$ & Population & $\begin{array}{c}\text { Sponsor/ } \\
\text { Collaborators }\end{array}$ & Locations \\
\hline 1 & NCT04324996 & $\begin{array}{l}\text { A Phase I/II Study of } \\
\text { Universal Off-the-shelf } \\
\text { NKG2D-ACE2 CAR-NK Cells } \\
\text { for Therapy of COVID-19 }\end{array}$ & Recruiting & - COVID-19 & $\begin{array}{l}\text { Cord blood :NKG2D } \\
\text { CAR- NK cells,ACE2 } \\
\text { CAR-NK cells, } \\
\text { NKG2D-ACE2 CAR- } \\
\text { NK cells }\end{array}$ & $\begin{array}{l}\text { - Biological: NK cells, } \\
\text { IL15-NK cells,NKG2D } \\
\text { CAR- NK cells,ACE2 CAR- } \\
\text { NK cells,NKG2D-ACE2 } \\
\text { CAR-NK cells }\end{array}$ & $\begin{array}{l}\text { Study Type: } \\
\text { Interventional } \\
\text { Phase: } \\
\text { - Phase } 1 \\
\text { - Phase } 2\end{array}$ & $\begin{array}{l}\text { Enrollment: } \\
90 \\
\text { Age: } \\
18 \text { Years } \\
\text { and older } \\
\text { (Adult, } \\
\text { Older Adult) } \\
\text { Sex: } \\
\|\end{array}$ & $\begin{array}{l}\text { - Chongqing } \\
\text { Public Health } \\
\text { Medical Center } \\
\text { • Chongqing } \\
\text { Sidemu Biotech } \\
\text { - Zhejiang } \\
\text { Qixin Biotech }\end{array}$ & $\begin{array}{l}\text { - Chongqing Public Health } \\
\text { Medical Center, Chongqing, China }\end{array}$ \\
\hline 2 & NCT03940833 & $\begin{array}{l}\text { Clinical Research of Adoptive } \\
\text { BCMA CAR-NK Cells on } \\
\text { Relapse/Refractory MM } \\
\text { Study Documents: }\end{array}$ & Recruiting & $\begin{array}{l}\text { - Multiple } \\
\text { Myeloma }\end{array}$ & $\begin{array}{l}\text { Engineered NK-92 } \\
\text { Cells }\end{array}$ & $\begin{array}{l}\text { - Biological: BCMA } \\
\text { CAR-NK } 92 \text { cells }\end{array}$ & $\begin{array}{l}\text { Study Type: } \\
\text { Interventional } \\
\text { Phase: } \\
\text { - Phase } 1 \\
\text { - } \quad \text { Phase } 2\end{array}$ & $\begin{array}{l}\text { Enrollment: } \\
20 \\
\text { Age: } \\
18 \text { Years to } \\
80 \text { Years } \\
\text { (Adult, } \\
\text { Older Adult) } \\
\text { Sex: } \\
\text { All }\end{array}$ & $\begin{array}{l}\text { - Asclepius } \\
\text { Technology } \\
\text { Company Group } \\
\text { (Suzhou) Co., } \\
\text { Ltd. }\end{array}$ & $\begin{array}{l}\text { - Department of Hematology, } \\
\text { Wuxi People's Hospital, Nanjing } \\
\text { Medical University, Wuxi, Jiangsu, } \\
\text { China }\end{array}$ \\
\hline 3 & NCT03940820 & $\begin{array}{l}\text { Clinical Research of ROBO1 } \\
\text { Specific CAR-NK Cells on } \\
\text { Patients With Solid Tumors } \\
\text { Study Documents: }\end{array}$ & Recruiting & $\begin{array}{l}\text { - Solid } \\
\text { Tumor }\end{array}$ & $\begin{array}{l}\text { ROBO1 Specific } \\
\text { CAR-NK Cells }\end{array}$ & $\begin{array}{l}\text { - Biological: ROBO1 } \\
\text { CAR-NK cells }\end{array}$ & $\begin{array}{l}\text { Study Type: } \\
\text { Interventional } \\
\text { Phase: } \\
\text { - Phase } 1 \\
\text { - } \quad \text { Phase } 2\end{array}$ & $\begin{array}{l}\text { Enrollment: } \\
20 \\
\text { Age: } \\
18 \text { Years to } \\
75 \text { Years } \\
\text { (Adult, } \\
\text { Older Adult) } \\
\text { Sex: } \\
\text { All }\end{array}$ & $\begin{array}{l}\text { - Asclepius } \\
\text { Technology } \\
\text { Company Group } \\
\text { (Suzhou) Co., } \\
\text { Ltd. }\end{array}$ & $\begin{array}{l}\text { - Radiation Therapy } \\
\text { Department, Suzhou Cancer } \\
\text { Center, Suzhou Hospital Affiliated } \\
\text { to Nanjing Medical University, } \\
\text { Suzhou, Jiangsu, China }\end{array}$ \\
\hline 4 & NCT04887012 & $\begin{array}{l}\text { Clinical Study of HLA } \\
\text { Haploidentical CAR-NK Cells } \\
\text { Targeting CD19 in the } \\
\text { Treatment of Refractory/ } \\
\text { Relapsed B-cell NHL } \\
\text { Study Documents: }\end{array}$ & Recruiting & $\begin{array}{l}\text { - B-cell Non } \\
\text { Hodgkin } \\
\text { Lymphoma }\end{array}$ & $\begin{array}{l}\text { HLA haploidentical } \\
\text { CAR-NK cells } \\
\text { targeting CD19 }\end{array}$ & $\begin{array}{l}\text { - Biological: anti- CD19 } \\
\text { CAR-NK }\end{array}$ & $\begin{array}{l}\text { Study Type: } \\
\text { Interventional } \\
\text { Phase: } \\
\text { Phase } 1\end{array}$ & $\begin{array}{l}\text { Enrollment: } \\
25 \\
\text { Age: } \\
18 \text { Years to } \\
75 \text { Years } \\
\text { (Adult, } \\
\text { Older Adult) } \\
\text { Sex: } \\
\text { All }\end{array}$ & $\begin{array}{l}\text { - Second } \\
\text { Affiliated } \\
\text { Hospital, School } \\
\text { of Medicine, } \\
\text { Zhejiang } \\
\text { University }\end{array}$ & $\begin{array}{l}\text { - 2nd Affiliated Hospital, School } \\
\text { of Medicine, Zhejiang University, } \\
\text { Hangzhou, Zhejiang, China }\end{array}$ \\
\hline 5 & NCT05020678 & $\begin{array}{l}\text { NKX019, Intravenous } \\
\text { Allogeneic Chimeric Antigen } \\
\text { Receptor Natural Killer Cells } \\
\text { (CAR NK), in Adults With B- } \\
\text { cell Cancers } \\
\text { Study Documents: }\end{array}$ & Recruiting & $\begin{array}{l}\text { •ymphoma, } \\
\text { Non- Hodgkin } \\
\text { - B-cell } \\
\text { Acute } \\
\text { Lymphoblastic } \\
\text { Leukemia } \\
\text { - Large B- } \\
\text { cell Lymphoma } \\
\text { - Mantle } \\
\text { Cell } \\
\text { Lymphoma }\end{array}$ & $\begin{array}{l}\text { allogeneic CAR NK } \\
\text { cells targeting CD19 }\end{array}$ & - Biological: NKX019 & $\begin{array}{l}\text { Study Type: } \\
\text { Interventional } \\
\text { Phase: } \\
\text { Phase } 1\end{array}$ & $\begin{array}{l}\text { Enrollment: } \\
60 \\
\text { Age: } \\
18 \text { Years } \\
\text { and older } \\
\text { (Adult, } \\
\text { Older Adult) } \\
\text { Sex: } \\
\text { All }\end{array}$ & - Nkarta Inc. & $\begin{array}{l}\text { - Colorado Blood Cancer } \\
\text { Institute, Denver, Colorado, United } \\
\text { States } \\
\text { - Peter MacCallum Cancer } \\
\text { Center, Melbourne, Victoria, } \\
\text { Australia }\end{array}$ \\
\hline
\end{tabular}




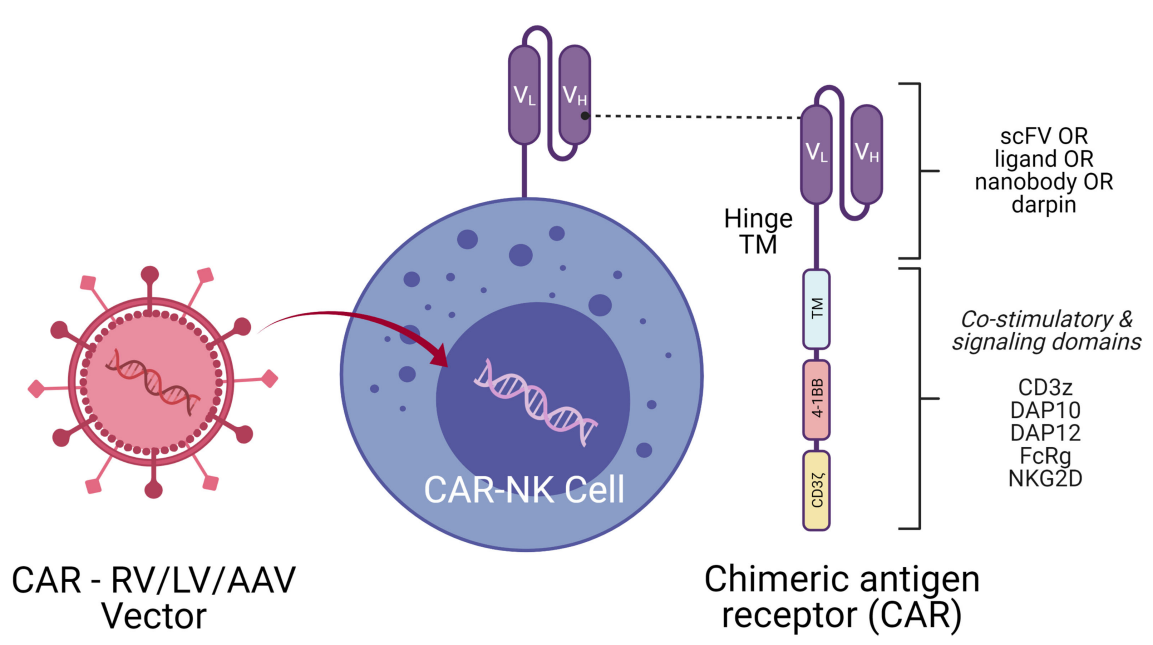

FIGURE 6 | CAR-NK Molecule Delivery of genetic cargo into NK cells with CAR encoding retro (RV), lenti (LV), or adeno-associated (AAV) vectors. CAR molecule is shown on the right side with single-chain variable fragment (scFv including $V_{H}$ and $V_{L}$ chains), hinge, transmembrane (TM), and signaling domain. Co-stimulatory signaling domains are indicated in different colors.

should be an essential consideration for CAR-NK generation. The advantages and disadvantages of different LV pseudotypes have been recently reviewed $(120,121)$.

\section{Adeno Associated Viral Delivery}

Alternative viral vectors with a better safety profile are adenovirus-associated virus (AAV) vectors. One way to improve the efficiency of NK cell cytotoxicity is by blocking their inhibitory receptors. Using CRISPR/cas9 driven delivery by recombinant adeno-associated virus serotype6 (rAAV6), highly efficient knockout of A Disintegrin and Metalloproteinase-17 (ADAM17) and programmed cell death 1 (PDCD1) genes in NK cells was accomplished (121). KO of ADAM17 and PDCD1 improved NK activity, cytokine production and cancer cell cytotoxicity. These approaches demonstrate an easy-to-use strategy for efficient gene editing and delivery with AAV vector systems for NK cell therapies (121). However, one limitation with AAV is its packaging capacity $(\sim 5 \mathrm{~kb})$ that limits a large gene transfer. NK cells in general have a low propensity for viral transduction, and higher cell death. Hence, commercially available viral transduction enhancers such as LentiBOOST, PGE2, PS, Vectofusin-1, ViraDuctin, Retronectin, Stauro and 7-hydroxy stauro are sometimes employed to improve vector transduction.

TABLE 4 | Advantages and disadvantages with different gene delivery vectors.

\begin{tabular}{|c|c|c|}
\hline Vector & Advantages & Drawbacks \\
\hline \multicolumn{3}{|l|}{ Viral Vectors } \\
\hline Adenovirus & - $\quad$ Deliver large dsDNA ( 8kb) & $\begin{array}{l}\text { - } \quad \text { Transient expression } \\
\text { - } \quad \text { Elicit immune response }\end{array}$ \\
\hline Adeno-associated virus & $\begin{array}{l}\text { - } \quad \text { Deliver to dividing and nondividing cells } \\
\text { - }\end{array}$ & $\begin{array}{ll}\text { - } & \text { Difficulty producing vectors } \\
\text { - } & \text { Limited transgene } \\
\text { - } & \text { Elicit immune response }\end{array}$ \\
\hline Retrovirus & $\begin{array}{ll}\text { - } & \text { Deliver to dividing cells } \\
\text { - } & \text { Sustained vector expression } \\
& \text { ssRNA ( 8kb) }\end{array}$ & $\begin{array}{ll}\text { - } & \text { cannot transfect non-dividing cells } \\
\text { - } & \text { Low transfection rate in vivo } \\
\text { - } & \text { Elicit immune response } \\
\text { - } & \text { Risk of insertion }\end{array}$ \\
\hline Lentivirus & $\begin{array}{ll}\text { - } & \text { Deliver to non-dividing cells } \\
\text { - } & \text { Genome integration into host } \\
\text { - } & \text { ssRNA }(\sim 8 \mathrm{~kb})\end{array}$ & - Possibility for insertional mutagenesis \\
\hline Non-Viral Vectors & $\begin{array}{ll}\text { - } & \text { Less/No insertional mutagenesis } \\
\text { - } & \text { Low/No immunogenicity } \\
\text { - } & \text { Can scale-up } \\
\text { - } & \text { Can be chemically modified } \\
\text { - } & \text { Relatively less expensive }\end{array}$ & $\begin{array}{l}\text { - } \quad \text { Less effective } \\
\text { - } \quad \text { Transient expression }\end{array}$ \\
\hline
\end{tabular}




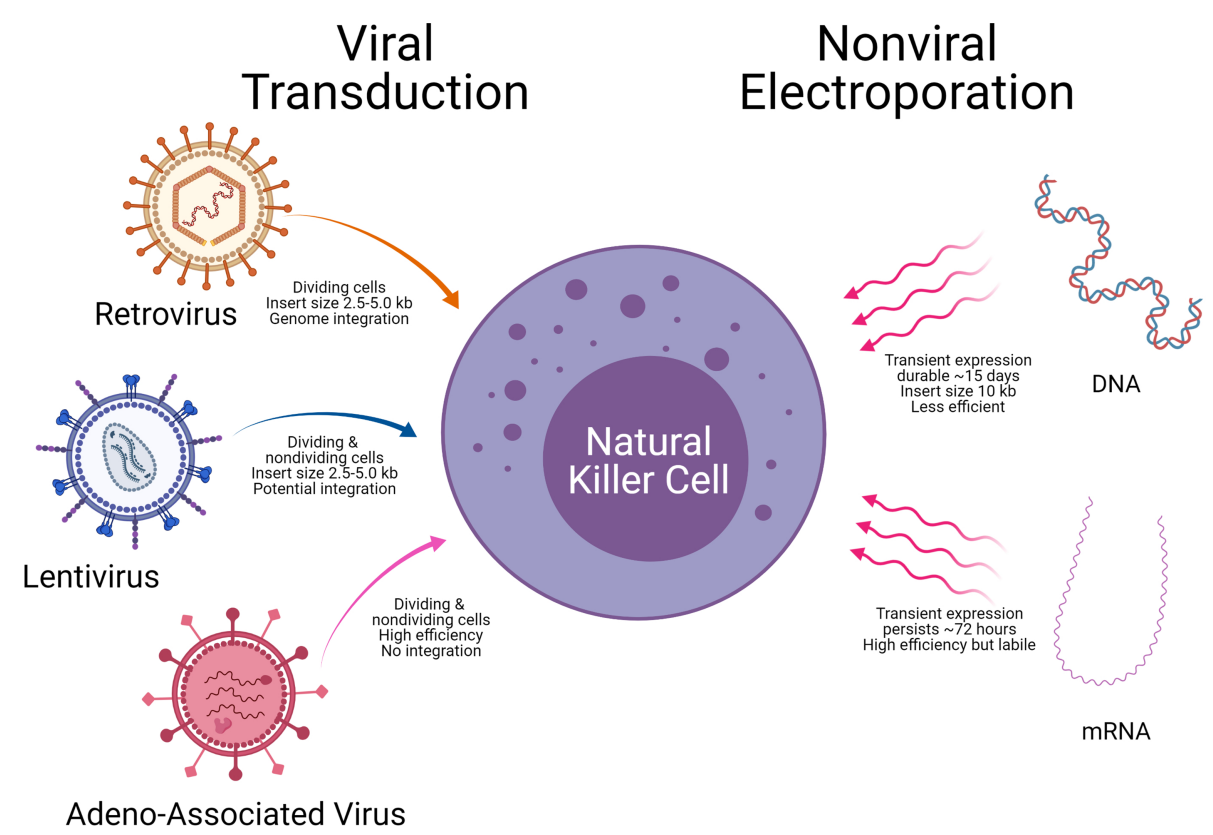

FIGURE 7 | Delivery technologies to engineer Natural killer cells. Modes of genetic cargo delivery into NK Cells by viral transduction and non-viral electroporation for gene engineering of NK Cells. Specific advantages and limitations are noted below the arrows.

\section{Non-Viral DNA Transfection and mRNA-Electroporation}

Successful electroporation of DNA into the NK-92 cancer cell line was shown, but not in primary NK cells from PBMCs or cord blood (33). Recently, an improved method with NK cells expanded with IL-2 was reported with $40 \%$ efficiency of DNA plasmid transfer (122). Following DNA transfer by electroporation, the viability of $\mathrm{NK}$ cells was lower, due to harsh electroporation conditions, and the DNA transfection efficiency was less compared to resting NK cells. The real advantage of this approach is complex constructs can also be transferred efficiently into the cells. Plasmid DNA of small $(\sim 3.5 \mathrm{~Kb})$ and large sizes $(\sim 12.5 \mathrm{~Kb})$ are transferred with a substantial increase of transfection up to 5-fold compared to the standard electroporation approach (123).

Some researchers are exploring electroporation to express CAR molecules on NK cells $(124,125)$. Unlike DNA electroporation, mRNA electroporation of NK cells may be an efficient alternative, but it induces only transient expression of the transferred gene. mRNA electroporation efficiencies are usually high (80-90\%) for PBMCs or cord blood cells and require cytokine stimulation such as IL-2 for post-transduction expansion or the use of feeder cells that are engineered to secrete IL2 for better viability of cells (126). Transfection efficiency with mRNA by electroporation depends on the dose of mRNA (25$200 \mathrm{ug} / \mathrm{ml}$ ) (127). High dose of mRNA results in poor viability of cells following transfection. In general, post electroporation expansion is contraindicated with mRNA approaches as it leads to dilution of the mRNA.
Recently another charge-based chemical method has been tried successfully to deliver CAR mRNA into non-dividing NK cells using a nucleofection approach that showed high efficiency (128). A specific advantage of using mRNA delivery system is the transient expression of protein by mRNA, thus avoids the risk of genome integration, least expensive to manufacture and savings of time (129). Another strategy that has been less frequently used for stable non-viral gene delivery is employing DNA transposons to transduce NK cells which is cost effective, has large cargo (ex: CAR in combination with activating receptors or cytokines) deliver capacity with stable integration. Their disadvantages include potential insertional mutagenesis and the transposon must be delivered as DNA $(130,131)$. Despite the limitations described above, the most successful non-viral gene delivery for primary NK cells is still rapid transient expression by electroporation.

\section{Engineering NK Cell Receptors}

For CAR-engineered cells to act, identifying specific tumor antigens as targets is a challenge, whether for $\mathrm{T}$ cells or NK cells. Human NK cells have innate inhibitory receptors such as KIRs and NKG2A molecules that recognize MHC class I and evoke response through immunoreceptors tyrosine-based inhibitory motif (ITIM). T cell immunoreceptor with immunoglobulin and ITIM domain (TIGIT) is an inhibitory receptor expressed on $\mathrm{T}$ and $\mathrm{NK}$ cells and is a promising emerging target for cancer immunotherapy. TIGIT interacts with ligands CD115 and CD112 expressed on tumor cells. There is evidence that TIGIT blockade can help tumor regression (132). 
In contrast, activating receptors on NK cells such as NKG2D and DNAX accessory molecule 1 (DNAM-1) play a crucial role in tumor surveillance since this receptor has a wide range of ligands that provide target specificity (133). Preclinical study data using CAR-NKG2D is promising in colorectal cancer patients (124) and multiple myeloma patients (134). Natural cytotoxicity receptors (NCRs) like NKp30, NKp44, and NKp46, can recognize multiple stress ligands in infection and oncogenic transformation. Harnessing these receptors on NK cells and their ligands on tumor cells is another new strategy to create CAR-NK cells that can induce anti-tumor immunity.

With the advances made in viral and non-viral gene delivery approaches to generate better CAR-NK molecules, there will be a heightened focus on how these cells perform in clinical trials over the next few years. These results will help determine whether CAR-NKs can effectively target and kill tumor cells (135). The viability of CAR-NK cells in the tumor microenvironment is central to the success of therapy, in addition to the repeated dosing of the cells. CAR engineering of NK cells primarily resides between two choices of stable high expression by viral vectors or rapid transient expression of non-viral delivery systems using electroporation.

\section{CONCLUSIONS AND PERSPECTIVES}

NK cells are critical in immune surveillance of invading viruses and kill tumor cells without the need of tumor specific antigen presentation. Pre-clinical data from early phase clinical trials has significantly increased our knowledge for the use of allogeneic donor NK cells across a wide range of hematological malignancies and solid tumors. Recent advances include developing NK cell expansion protocols without the use of feeders, serum, activation technologies, validation of NK cells from different tissue sources, ability to selectively use donor NK cells with minimal HLA

\section{REFERENCES}

1. Bryceson YT, March ME, Barber DF, Ljunggren HG, Long EO. Cytolytic Granule Polarization and Degranulation Controlled by Different Receptors in Resting NK Cells. J Exp Med (2005) 202:1001-12. doi: 10.1084/jem.20051143

2. Gunesch JT, Angelo LS, Mahapatra S, Deering RP, Kowalko JE, Sleiman P, et al. Genome-Wide Analyses and Functional Profiling of Human NK Cell Lines. Mol Immunol (2019) 115:64-75. doi: 10.1016/j.molimm.2018.07.015

3. Shimasaki N, Jain A, Campana D. NK Cells for Cancer Immunotherapy. Nat Rev Drug Discov (2020) 19:200-18. doi: 10.1038/s41573-019-0052-1

4. Caligiuri MA. Human Natural Killer Cells. Blood (2008) 112:461-9. doi: 10.1182/blood-2007-09-077438

5. Wu SY, Fu T, Jiang YZ, Shao ZM. Natural Killer Cells in Cancer Biology and Therapy. Mol Cancer (2020) 19:120. doi: 10.1186/s12943-020-01238-x

6. Cooper MA, Fehniger TA, Caligiuri MA. The Biology of Human Natural Killer-Cell Subsets. Trends Immunol (2001) 22:633-40. doi: 10.1016/S14714906(01)02060-9

7. Angelo LS, Banerjee PP, Monaco-Shawver L, Rosen JB, Makedonas G, Forbes LR, et al. Practical NK Cell Phenotyping and Variability in Healthy Adults. Immunol Res (2015) 62:341-56. doi: 10.1007/s12026-015-8664-y

8. Dogra P, Rancan C, Ma W, Toth M, Senda T, Carpenter DJ, et al. Tissue Determinants of Human NK Cell Development, Function, and Residence. Cell (2020) 180:749-63.e13. doi: 10.1016/j.cell.2020.01.022 matching, genetic modification to create CAR-NK constructs, and transfer of genetic material using viral and nonviral delivery technologies. These advances point towards a true "off-the-shelf" NK cell therapy. Despite impressive advances, there are multiple outstanding challenges with NK cell therapies. Methods following good manufacturing practices to generate large clinical doses from a single healthy donor and selective expansion appropriate NK cell subsets with best predictive KIR/HLA are needed. Additionally, tumor immune evasion remains a large barrier. Once the NK or CAR-NK cells are infused into the patient, the long-term persistence of these cells in-vivo in the tumor microenvironment needs to be ensured and monitored. Another limitation with NK and CAR-NK cells is the memory property in vivo, which is not fully understood as in the case of memory $\mathrm{T}$ cells in adaptive immunity. Identifying novel CAR targets and generation of NK specific CAR constructs will enable CAR-NK cell homing and persistence in solid tumors contributing to breakthrough approaches driving allogeneic NK therapies towards the next frontier of cancer immunotherapy.

\section{AUTHOR CONTRIBUTIONS}

$\mathrm{EH}, \mathrm{EZ}, \mathrm{TS}, \mathrm{AH}, \mathrm{NK}$ and MCV wrote the manuscript and, SB prepared figures. All authors contributed to the article and approved the submitted version.

\section{ACKNOWLEDGMENTS}

The authors thank Dr. Jonathan Chesnut for the support, review and Dr. Premkumar Jayaraman for proofreading the manuscript. Further, the authors acknowledge BioRender (BioRender.com) for the software to create figures.

9. Lopez-Verges S, Milush JM, Pandey S, York VA, Arakawa-Hoyt J, Pircher $\mathrm{H}$, et al. CD57 Defines a Functionally Distinct Population of Mature NK Cells in the Human CD56dimCD16+ NK-Cell Subset. Blood (2010) 116:3865-74. doi: 10.1182/blood-2010-04-282301

10. Bjorkstrom NK, Ljunggren HG, Michaelsson J. Emerging Insights Into Natural Killer Cells in Human Peripheral Tissues. Nat Rev Immunol (2016) 16:310-20. doi: 10.1038/nri.2016.34

11. Smyth MJ, Cretney E, Kelly JM, Westwood JA, Street SE, Yagita H, et al. Activation of NK Cell Cytotoxicity. Mol Immunol (2005) 42:501-10. doi: 10.1016/j.molimm.2004.07.034

12. Arnould L, Gelly M, Penault-Llorca F, Benoit L, Bonnetain F, Migeon C, et al. Trastuzumab-Based Treatment of HER2-Positive Breast Cancer: An Antibody-Dependent Cellular Cytotoxicity Mechanism? Br J Cancer (2006) 94:259-67. doi: 10.1038/sj.bjc.6602930

13. Choucair K, Morand S, Stanbery L, Edelman G, Dworkin L, Nemunaitis J. TMB: A Promising Immune-Response Biomarker, and Potential Spearhead in Advancing Targeted Therapy Trials. Cancer Gene Ther (2020) 27:841-53. doi: 10.1038/s41417-020-0174-y

14. Shenouda MM, Gillgrass A, Nham T, Hogg R, Lee AJ, Chew MV, et al. Ex Vivo Expanded Natural Killer Cells From Breast Cancer Patients and Healthy Donors Are Highly Cytotoxic Against Breast Cancer Cell Lines and Patient-Derived Tumours. Breast Cancer Res (2017) 19:76. doi: 10.1186/ s13058-017-0867-9 
15. Ruggeri L, Mancusi A, Capanni M, Martelli MF, Velardi A. Exploitation of Alloreactive NK Cells in Adoptive Immunotherapy of Cancer. Curr Opin Immunol (2005) 17:211-7. doi: 10.1016/j.coi.2005.01.007

16. Sheng L, Mu Q, Wu X, Yang S, Zhu H, Wang J, et al. Cytotoxicity of Donor Natural Killer Cells to Allo-Reactive T Cells Are Related With Acute GraftVs-Host-Disease Following Allogeneic Stem Cell Transplantation. Front Immunol (2020) 11:1534. doi: 10.3389/fimmu.2020.01534

17. Verneris MR, Miller JS. The Phenotypic and Functional Characteristics of Umbilical Cord Blood and Peripheral Blood Natural Killer Cells. $\mathrm{Br} \mathrm{J}$ Haematol (2009) 147:185-91. doi: 10.1111/j.1365-2141.2009.07768.x

18. Miller JS, Soignier Y, Panoskaltsis-Mortari A, McNearney SA, Yun GH, Fautsch SK, et al. Successful Adoptive Transfer and In Vivo Expansion of Human Haploidentical NK Cells in Patients With Cancer. Blood (2005) 105:3051-7. doi: 10.1182/blood-2004-07-2974

19. Romee R, Rosario M, Berrien-Elliott MM, Wagner JA, Jewell BA, Schappe T, et al. Cytokine-Induced Memory-Like Natural Killer Cells Exhibit Enhanced Responses Against Myeloid Leukemia. Sci Transl Med (2016) 8:357ra123. doi: 10.1126/scitranslmed.aaf2341

20. Huang Q, Huang M, Meng F, Sun R. Activated Pancreatic Stellate Cells Inhibit NK Cell Function in the Human Pancreatic Cancer Microenvironment. Cell Mol Immunol (2019) 16:87-9. doi: 10.1038/ s41423-018-0014-2

21. Klingemann H, Boissel L, Toneguzzo F. Natural Killer Cells for Immunotherapy - Advantages of the NK-92 Cell Line Over Blood NK Cells. Front Immunol (2016) 7:91. doi: 10.3389/fimmu.2016.00091

22. Passweg JR, Tichelli A, Meyer-Monard S, Heim D, Stern M, Kuhne T, et al. Purified Donor NK-Lymphocyte Infusion to Consolidate Engraftment After Haploidentical Stem Cell Transplantation. Leukemia (2004) 18:1835-8. doi: 10.1038/sj.leu.2403524

23. Tonn T, Schwabe D, Klingemann HG, Becker S, Esser R, Koehl U, et al. Treatment of Patients With Advanced Cancer With the Natural Killer Cell Line NK-92. Cytotherapy (2013) 15:1563-70. doi: 10.1016/j.jcyt.2013.06.017

24. Knorr DA, Ni Z, Hermanson D, Hexum MK, Bendzick L, Cooper LJ, et al. Clinical-Scale Derivation of Natural Killer Cells From Human Pluripotent Stem Cells for Cancer Therapy. Stem Cells Transl Med (2013) 2:274-83. doi: 10.5966/sctm.2012-0084

25. Ni Z, Knorr DA, Clouser CL, Hexum MK, Southern P, Mansky LM, et al. Human Pluripotent Stem Cells Produce Natural Killer Cells That Mediate Anti-HIV-1 Activity by Utilizing Diverse Cellular Mechanisms. J Virol (2011) 85:43-50. doi: 10.1128/JVI.01774-10

26. Woll PS, Grzywacz B, Tian X, Marcus RK, Knorr DA, Verneris MR, et al. Human Embryonic Stem Cells Differentiate Into a Homogeneous Population of Natural Killer Cells With Potent In Vivo Antitumor Activity. Blood (2009) 113:6094-101. doi: 10.1182/blood-2008-06-165225

27. Condiotti R, Zakai YB, Barak V, Nagler A. Ex Vivo Expansion of CD56+ Cytotoxic Cells From Human Umbilical Cord Blood. Exp Hematol (2001) 29:104-13. doi: 10.1016/S0301-472X(00)00617-2

28. Shah N, Martin-Antonio B, Yang H, Ku S, Lee DA, Cooper LJ, et al. Antigen Presenting Cell-Mediated Expansion of Human Umbilical Cord Blood Yields Log-Scale Expansion of Natural Killer Cells With Anti-Myeloma Activity. PLoS One (2013) 8:e76781. doi: 10.1371/journal.pone.0076781

29. Araki H, Yoshinaga K, Boccuni P, Zhao Y, Hoffman R, Mahmud N. Chromatin-Modifying Agents Permit Human Hematopoietic Stem Cells to Undergo Multiple Cell Divisions While Retaining Their Repopulating Potential. Blood (2007) 109:3570-8. doi: 10.1182/blood-2006-07-035287

30. Dolstra H, Roeven MWH, Spanholtz J, Hangalapura BN, Tordoir M, Maas F, et al. Successful Transfer of Umbilical Cord Blood CD34(+) Hematopoietic Stem and Progenitor-Derived NK Cells in Older Acute Myeloid Leukemia Patients. Clin Cancer Res (2017) 23:4107-18. doi: 10.1158/1078-0432.CCR-16-2981

31. Kundu S, Gurney M, O’Dwyer M. Generating Natural Killer Cells for Adoptive Transfer: Expanding Horizons. Cytotherapy (2021) 23:559-66. doi: $10.1016 /$ j.jcyt.2020.12.002

32. Dalle JH, Menezes J, Wagner E, Blagdon M, Champagne J, Champagne MA, et al. Characterization of Cord Blood Natural Killer Cells: Implications for Transplantation and Neonatal Infections. Pediatr Res (2005) 57:649-55. doi: 10.1203/01.PDR.0000156501.55431.20

33. Herrera L, Santos S, Vesga MA, Anguita J, Martin-Ruiz I, Carrascosa T, et al. Adult Peripheral Blood and Umbilical Cord Blood NK Cells Are Good
Sources for Effective CAR Therapy Against CD19 Positive Leukemic Cells. Sci Rep (2019) 9:18729. doi: 10.1038/s41598-019-55239-y

34. Oberoi P, Kamenjarin K, Ossa JFV, Uherek B, Bonig H, Wels WS. Directed Differentiation of Mobilized Hematopoietic Stem and Progenitor Cells Into Functional NK Cells With Enhanced Antitumor Activity. Cells (2020) 9. doi: $10.3390 /$ cells 9040811

35. Shankar K, Capitini CM, Saha K. Genome Engineering of Induced Pluripotent Stem Cells to Manufacture Natural Killer Cell Therapies. Stem Cell Res Ther (2020) 11:234. doi: 10.1186/s13287-020-01741-4

36. Yoon SR, Lee YS, Yang SH, Ahn KH, Lee JH, Lee JH, et al. Generation of Donor Natural Killer Cells From CD34(+) Progenitor Cells and Subsequent Infusion After HLA-Mismatched Allogeneic Hematopoietic Cell Transplantation: A Feasibility Study. Bone Marrow Transplant (2010) 45:1038-46. doi: 10.1038/bmt.2009.304

37. Mark C, Czerwinski T, Roessner S, Mainka A, Horsch F, Heublein L, et al. Cryopreservation Impairs 3-D Migration and Cytotoxicity of Natural Killer Cells. Nat Commun (2020) 11:5224. doi: 10.1038/s41467-020-19094-0

38. Williams SM, Sumstad D, Kadidlo D, Curtsinger J, Luo X, Miller JS, et al. Clinical-Scale Production of cGMP Compliant CD3/CD19 Cell-Depleted NK Cells in the Evolution of NK Cell Immunotherapy at a Single Institution. Transfusion (2018) 58:1458-67. doi: 10.1111/trf.14564

39. Fujisaki H, Kakuda H, Shimasaki N, Imai C, Ma J, Lockey T, et al. Expansion of Highly Cytotoxic Human Natural Killer Cells for Cancer Cell Therapy. Cancer Res (2009) 69:4010-7. doi: 10.1158/0008-5472.CAN-08-3712

40. Zhu H, Kaufman DS. An Improved Method to Produce Clinical-Scale Natural Killer Cells From Human Pluripotent Stem Cells. Methods Mol Biol (2019) 2048:107-19. doi: 10.1007/978-1-4939-9728-2_12

41. Ni Z, Knorr DA, Kaufman DS. Hematopoietic and Nature Killer Cell Development From Human Pluripotent Stem Cells. Methods Mol Biol (2013) 1029:33-41. doi: 10.1007/978-1-62703-478-4_3

42. Hartfield EM, Yamasaki-Mann M, Ribeiro Fernandes HJ, Vowles J, James WS, Cowley SA, et al. Physiological Characterisation of Human iPS-Derived Dopaminergic Neurons. PLoS One (2014) 9:e87388. doi: 10.1371/journal. pone. 0087388

43. Malik N, Rao MS. A Review of the Methods for Human iPSC Derivation. Methods Mol Biol (2013) 997:23-33. doi: 10.1007/978-1-62703-348-0_3

44. Ludwig TE, Bergendahl V, Levenstein ME, Yu J, Probasco MD, Thomson JA. Feeder-Independent Culture of Human Embryonic Stem Cells. Nat Methods (2006) 3:637-46. doi: 10.1038/nmeth902

45. Chen Y, You F, Jiang L, Li J, Zhu X, Bao Y, et al. Gene-Modified NK-92MI Cells Expressing a Chimeric CD16-BB-Zeta or CD64-BB-Zeta Receptor Exhibit Enhanced Cancer-Killing Ability in Combination With Therapeutic Antibody. Oncotarget (2017) 8:37128-39. doi: 10.18632/oncotarget.16201

46. Boyiadzis M, Agha M, Redner RL, Sehgal A, Im A, Hou JZ, et al. Phase 1 Clinical Trial of Adoptive Immunotherapy Using "Off-the-Shelf” Activated Natural Killer Cells in Patients With Refractory and Relapsed Acute Myeloid Leukemia. Cytotherapy (2017) 19:1225-32. doi: 10.1016/j.jcyt.2017.07.008

47. Williams BA, Law AD, Routy B, denHollander N, Gupta V, Wang XH, et al. A Phase I Trial of NK-92 Cells for Refractory Hematological Malignancies Relapsing After Autologous Hematopoietic Cell Transplantation Shows Safety and Evidence of Efficacy. Oncotarget (2017) 8:89256-68. doi: 10.18632/oncotarget.19204

48. Nowakowska P, Romanski A, Miller N, Odendahl M, Bonig H, Zhang C, et al. Clinical Grade Manufacturing of Genetically Modified, CAR-Expressing NK92 Cells for the Treatment of ErbB2-Positive Malignancies. Cancer Immunol Immunother (2018) 67:25-38. doi: 10.1007/s00262-017-2055-2

49. Matosevic S. Viral and Nonviral Engineering of Natural Killer Cells as Emerging Adoptive Cancer Immunotherapies. J Immunol Res (2018) 2018:4054815. doi: 10.1155/2018/4054815

50. Phillips JH, Lanier LL. A Model for the Differentiation of Human Natural Killer Cells. Studies on the In Vitro Activation of Leu-11+ Granular Lymphocytes With a Natural Killer-Sensitive Tumor Cell, K562. J Exp Med (1985) 161:1464-82. doi: 10.1084/jem.161.6.1464

51. Granzin M, Stojanovic A, Miller M, Childs R, Huppert V, Cerwenka A. Highly Efficient IL-21 and Feeder Cell-Driven Ex Vivo Expansion of Human NK Cells With Therapeutic Activity in a Xenograft Mouse Model of Melanoma. Oncoimmunology (2016) 5:e1219007. doi: 10.1080/ 2162402X.2016.1219007 
52. Baggio L, Laureano AM, Silla L, Lee DA. Natural Killer Cell Adoptive Immunotherapy: Coming of Age. Clin Immunol (2017) 177:3-11. doi: 10.1016/j.clim.2016.02.003

53. Luhm J, Brand JM, Koritke P, Hoppner M, Kirchner H, Frohn C. Large-Scale Generation of Natural Killer Lymphocytes for Clinical Application. -J Hematother Stem Cell Res (2002) 11:651-7. doi: 10.1089/15258160260194794

54. Lim SA, Kim TJ, Lee JE, Sonn CH, Kim K, Kim J, et al. Ex Vivo Expansion of Highly Cytotoxic Human NK Cells by Cocultivation With Irradiated Tumor Cells for Adoptive Immunotherapy. Cancer Res (2013) 73:2598-607. doi: 10.1158/0008-5472.CAN-12-2893

55. Kobayashi M, Fitz L, Ryan M, Hewick RM, Clark SC, Chan S, et al. Identification and Purification of Natural Killer Cell Stimulatory Factor (NKSF), a Cytokine With Multiple Biologic Effects on Human Lymphocytes. J Exp Med (1989) 170:827-45. doi: 10.1084/jem.170.3.827

56. Warren HS, Kinnear BF, Skipsey LJ. Human Natural Killer (NK) Cells: Requirements for Cell Proliferation and Expansion of Phenotypically Novel Subpopulations. Immunol Cell Biol (1993) 71(Pt 2):87-97. doi: 10.1038/ icb.1993.9

57. Lapteva N, Durett AG, Sun J, Rollins LA, Huye LL, Fang J, et al. Large-Scale Ex Vivo Expansion and Characterization of Natural Killer Cells for Clinical Applications. Cytotherapy (2012) 14:1131-43. doi: 10.3109/14653249. 2012.700767

58. Fuchshuber PR, Lotzova E. Feeder Cells Enhance Oncolytic and Proliferative Activity of Long-Term Human Bone Marrow Interleukin-2 Cultures and Induce Different Lymphocyte Subsets. Cancer Immunol Immunother (1991) 33:15-20. doi: 10.1007/BF01742522

59. Yang Y, Lim O, Kim TM, Ahn YO, Choi H, Chung H, et al. Phase I Study of Random Healthy Donor-Derived Allogeneic Natural Killer Cell Therapy in Patients With Malignant Lymphoma or Advanced Solid Tumors. Cancer Immunol Res (2016) 4:215-24. doi: 10.1158/2326-6066.CIR-15-0118

60. Min B, Choi H, Her JH, Jung MY, Kim HJ, Jung MY, et al. Optimization of Large-Scale Expansion and Cryopreservation of Human Natural Killer Cells for Anti-Tumor Therapy. Immune Netw (2018) 18:e31. doi: 10.4110/in.2018. 18.e31

61. Denman CJ, Senyukov VV, Somanchi SS, Phatarpekar PV, Kopp LM, Johnson JL, et al. Membrane-Bound IL-21 Promotes Sustained Ex Vivo Proliferation of Human Natural Killer Cells. PLoS One (2012) 7:e30264. doi: 10.1371/journal.pone.0030264

62. Lee DA. Regulatory Considerations for NK Cells Used in Human Immunotherapy Applications. Methods Mol Biol (2016) 1441:347-61. doi: 10.1007/978-1-4939-3684-7_29

63. Koehl U, Kalberer C, Spanholtz J, Lee DA, Miller JS, Cooley S, et al. Advances in Clinical NK Cell Studies: Donor Selection, Manufacturing and Quality Control. Oncoimmunology (2016) 5:e1115178. doi: 10.1080/ 2162402X.2015.1115178

64. Geller MA, Cooley S, Judson PL, Ghebre R, Carson LF, Argenta PA, et al. A Phase II Study of Allogeneic Natural Killer Cell Therapy to Treat Patients With Recurrent Ovarian and Breast Cancer. Cytotherapy (2011) 13:98-107. doi: 10.3109/14653249.2010.515582

65. Choi SS, Chhabra VS, Nguyen QH, Ank BJ, Stiehm ER, Roberts RL. Interleukin-15 Enhances Cytotoxicity, Receptor Expression, and Expansion of Neonatal Natural Killer Cells in Long-Term Culture. Clin Diagn Lab Immunol (2004) 11:879-88. doi: 10.1128/CDLI.11.5.879888.2004

66. Waldmann TA. The Biology of Interleukin-2 and Interleukin-15: Implications for Cancer Therapy and Vaccine Design. Nat Rev Immunol (2006) 6:595-601. doi: 10.1038/nri1901

67. Marks-Konczalik J, Dubois S, Losi JM, Sabzevari H, Yamada N, Feigenbaum $\mathrm{L}$, et al. IL-2-Induced Activation-Induced Cell Death Is Inhibited in IL-15 Transgenic Mice. Proc Natl Acad Sci USA (2000) 97:11445-50. doi: 10.1073/ pnas. 200363097

68. Nelson BH. IL-2, Regulatory T Cells, and Tolerance. J Immunol (2004) 172:3983-8. doi: 10.4049/jimmunol.172.7.3983

69. Felices M, Lenvik A, Chu S, McElmurry R, Cooley S, Tolar J, et al. Continuous IL-15 Signaling Leads to Functional Exhaustion of Human Natural Killer Cells Through Metabolic Changes That Alters Their In Vivo Anti-Tumor Activity. Washington, DC: American Society of Hematology (2016).
70. Kasaian MT, Whitters MJ, Carter LL, Lowe LD, Jussif JM, Deng B, et al. IL21 Limits NK Cell Responses and Promotes Antigen-Specific T Cell Activation: A Mediator of the Transition From Innate to Adaptive Immunity. Immunity (2002) 16:559-69. doi: 10.1016/S1074-7613(02) 00295-9

71. Heinze A, Grebe B, Bremm M, Huenecke S, Munir TA, Graafen L, et al. The Synergistic Use of IL-15 and IL-21 for the Generation of NK Cells From CD3/CD19-Depleted Grafts Improves Their Ex Vivo Expansion and Cytotoxic Potential Against Neuroblastoma: Perspective for Optimized Immunotherapy Post Haploidentical Stem Cell Transplantation. Front Immunol (2019) 10. doi: 10.3389/fimmu.2019.02816

72. Wendt K, Wilk E, Buyny S, Schmidt RE, Jacobs R. Interleukin-21 Differentially Affects Human Natural Killer Cell Subsets. Immunology (2007) 122:486-95. doi: 10.1111/j.1365-2567.2007.02675.x

73. Park YK, Shin DJ, Cho D, Kim SK, Lee JJ, Shin MG, et al. Interleukin-21 Increases Direct Cytotoxicity and IFN-Gamma Production of Ex Vivo Expanded NK Cells Towards Breast Cancer Cells. Anticancer Res (2012) 32:839-46.

74. Skak K, Frederiksen KS, Lundsgaard D. Interleukin-21 Activates Human Natural Killer Cells and Modulates Their Surface Receptor Expression. Immunology (2008) 123:575-83. doi: 10.1111/j.1365-2567.2007.02730.x

75. D'Andrea A, Rengaraju M, Valiante NM, Chehimi J, Kubin M, Aste M, et al. Production of Natural Killer Cell Stimulatory Factor (Interleukin 12) by Peripheral Blood Mononuclear Cells. J Exp Med (1992) 176:1387-98. doi: 10.1084/jem.176.5.1387

76. Wang KS, Frank DA, Ritz J. Interleukin-2 Enhances the Response of Natural Killer Cells to Interleukin-12 Through Up-Regulation of the Interleukin-12 Receptor and STAT4. Blood (2000) 95:3183-90. doi: 10.1182/blood.V95. 10.3183

77. Choi YH, Lim EJ, Kim SW, Moon YW, Park KS, An HJ. Correction to: IL-27 Enhances IL-15/IL-18-Mediated Activation of Human Natural Killer Cells. J Immunother Cancer (2019) 7:211. doi: 10.1186/s40425-019-0688-8

78. French AR, Holroyd EB, Yang L, Kim S, Yokoyama WM. IL-18 Acts Synergistically With IL-15 in Stimulating Natural Killer Cell Proliferation. Cytokine (2006) 35:229-34. doi: 10.1016/j.cyto.2006.08.006

79. Romee R, Schneider SE, Leong JW, Chase JM, Keppel CR, Sullivan RP, et al. Cytokine Activation Induces Human Memory-Like NK Cells. Blood (2012) 120:4751-60. doi: 10.1182/blood-2012-04-419283

80. Cooper MA, Elliott JM, Keyel PA, Yang L, Carrero JA, Yokoyama WM. Cytokine-Induced Memory-Like Natural Killer Cells. Proc Natl Acad Sci USA (2009) 106:1915-9. doi: 10.1073/pnas.0813192106

81. Wu LS, Wang JY. Warm Up, Cool Down, and Tearing Apart in NK Cell Memory. Cell Mol Immunol (2018) 15:1095-7. doi: 10.1038/s41423-0180188-7

82. Ojo EO, Sharma AA, Liu R, Moreton S, Checkley-Luttge MA, Gupta K, et al. Membrane Bound IL-21 Based NK Cell Feeder Cells Drive Robust Expansion and Metabolic Activation of NK Cells. Sci Rep (2019) 9:14916. doi: 10.1038/s41598-019-51287-6

83. Szmania S, Lapteva N, Garg T, Greenway A, Lingo J, Nair B, et al. Ex VivoExpanded Natural Killer Cells Demonstrate Robust Proliferation In Vivo in High-Risk Relapsed Multiple Myeloma Patients. J Immunother (2015) 38:24-36. doi: 10.1097/CJI.0000000000000059

84. Ciurea SO, Schafer JR, Bassett R, Denman CJ, Cao K, Willis D, et al. Phase 1 Clinical Trial Using Mbil21 Ex Vivo-Expanded Donor-Derived NK Cells After Haploidentical Transplantation. Blood (2017) 130:1857-68. doi: 10.1182/blood-2017-05-785659

85. Oyer JL, Pandey V, Igarashi RY, Somanchi SS, Zakari A, Solh M, et al. Natural Killer Cells Stimulated With PM21 Particles Expand and Biodistribute In Vivo: Clinical Implications for Cancer Treatment. Cytotherapy (2016) 18:653-63. doi: 10.1016/j.jcyt.2016.02.006

86. Shah N, Li L, McCarty J, Kaur I, Yvon E, Shaim H, et al. Phase I Study of Cord Blood-Derived Natural Killer Cells Combined With Autologous Stem Cell Transplantation in Multiple Myeloma. Br J Haematol (2017) 177:45766. doi: 10.1111/bjh.14570

87. Kim EK, Ahn YO, Kim S, Kim TM, Keam B, Heo DS. Ex Vivo Activation and Expansion of Natural Killer Cells From Patients With Advanced Cancer With Feeder Cells From Healthy Volunteers. Cytotherapy (2013) 15:23141.e1. doi: 10.1016/j.jcyt.2012.10.019 
88. Lister J, Rybka WB, Donnenberg AD, deMagalhaes-Silverman M, Pincus SM, Bloom EJ, et al. Autologous Peripheral Blood Stem Cell Transplantation and Adoptive Immunotherapy With Activated Natural Killer Cells in the Immediate Posttransplant Period. Clin Cancer Res (1995) 1:607-14.

89. Meng Y, Sun J, Hu T, Ma Y, Du T, Kong C, et al. Rapid Expansion in the WAVE Bioreactor of Clinical Scale Cells for Tumor Immunotherapy. Hum Vaccin Immunother (2018) 14:2516-26. doi: 10.1080/21645515.2018. 1480241

90. Gratch Y, Bowles P, Krishnan R, Loo-Yong-Kee S, Iyer R, Dulgar-Tulloch A. A Semi-Automated, High-Purity Process for Natural Killer (NK) Cell Manufacturing in a Rocking Bioreactor. Cytotherapy (2018) 20:e8-9. doi: $10.1016 /$ j.jcyt.2018.03.029

91. Pierson BA, Europa AF, Hu WS, Miller JS. Production of Human Natural Killer Cells for Adoptive Immunotherapy Using a Computer-Controlled Stirred-Tank Bioreactor. J Hematother (1996) 5:475-83. doi: 10.1089/ scd.1.1996.5.475

92. Veluchamy J. An Off the Shelf, GMP Compliant, Fully Closed and SemiAutomated Large-Scale Production System for Allogeneic NK Cells. Cytotherapy (2020) 22:S161-2. doi: 10.1016/j.jcyt.2020.03.338

93. Kim J, Nam HJ, Lee SH, Ku JB, Han SR, Shin HJ, et al. Scale-Up Study for Ex-Vivo Expansion of Allogeneic Natural Killer Cells in Stirred-Tank Bioreactor. ECI conference in 2019 (2019). doi: 10.3390/cancers12040842

94. Broker K, Sinelnikov E, Gustavus D, Schumacher U, Portner R, Hoffmeister $\mathrm{H}$, et al. Mass Production of Highly Active NK Cells for Cancer Immunotherapy in a GMP Conform Perfusion Bioreactor. Front Bioeng Biotechnol (2019) 7:194. doi: 10.3389/fbioe.2019.00194

95. Berg M, Lundqvist A, McCoy PJr., Samsel L, Fan Y, Tawab A, et al. ClinicalGrade Ex Vivo-Expanded Human Natural Killer Cells Up-Regulate Activating Receptors and Death Receptor Ligands and Have Enhanced Cytolytic Activity Against Tumor Cells. Cytotherapy (2009) 11:341-55. doi: 10.1080/14653240902807034

96. Oh E, Min B, Lin Y, Lian C, Hong J, Park GM, et al. Cryopreserved Human Natural Killer Cells Exhibit Potent Antitumor Efficacy Against Orthotopic Pancreatic Cancer Through Efficient Tumor-Homing and Cytolytic Ability (Running Title: Cryopreserved NK Cells Exhibit Antitumor Effect). Cancers (Basel) (2020) 12:966. doi: 10.3390/cancers 12113255

97. Zou W. Mechanistic Insights Into Cancer Immunity and Immunotherapy. Cell Mol Immunol (2018) 15:419-20. doi: 10.1038/s41423-018-0011-5

98. Petty AJ, Heyman B, Yang Y. Chimeric Antigen Receptor Cell Therapy: Overcoming Obstacles to Battle Cancer. Cancers (Basel) (2020) 12. doi: $10.3390 /$ cancers 12040842

99. Depil S, Duchateau P, Grupp S, Mufti G, Poirot L. 'Off-The-Shelfallogeneic CAR T Cells: Development and Challenges. Nat Rev Drug Discov (2020) 19:185-99. doi: 10.1038/s41573-019-0051-2

100. Lupo KB, Matosevic S. Natural Killer Cells as Allogeneic Effectors in Adoptive Cancer Immunotherapy. Cancers (2019) 11:769. doi: 10.3390/ cancers 11060769

101. Chou CK, Turtle CJ. Assessment and Management of Cytokine Release Syndrome and Neurotoxicity Following CD19 CAR-T Cell Therapy. Expert Opin Biol Ther (2020) 20:653-64. doi: 10.1080/14712598.2020.1729735

102. Lin C, Zhang J. Reformation in Chimeric Antigen Receptor Based Cancer Immunotherapy: Redirecting Natural Killer Cell. Biochim Biophys Acta (BBA)-Rev Cancer (2018) 1869:200-15. doi: 10.1016/j.bbcan.2018.01.005

103. Bhatnagar N, Ahmad F, Hong HS, Eberhard J, Lu IN, Ballmaier M, et al. FcgammaRIII (CD16)-Mediated ADCC by NK Cells Is Regulated by Monocytes and FcgammaRII (Cd32). Eur J Immunol (2014) 44:3368-79. doi: 10.1002/eji.201444515

104. Morgan MA, Büning H, Sauer M, Schambach A. Use of Cell and Genome Modification Technologies to Generate Improved "Off-the-Shelf" CAR T and CAR NK Cells. Front Immunol (2020) 11:1965. doi: 10.3389/ fimmu.2020.01965

105. Li Y, Hermanson DL, Moriarity BS, Kaufman DS. Human iPSC-Derived Natural Killer Cells Engineered With Chimeric Antigen Receptors Enhance Anti-Tumor Activity. Cell Stem Cell (2018) 23:181-92.e5. doi: 10.1016/ j.stem.2018.06.002

106. Gong Y, Klein Wolterink RGJ, Wang J, Bos GMJ, Germeraad WTV. Chimeric Antigen Receptor Natural Killer (CAR-NK) Cell Design and Engineering for
Cancer Therapy. J Hematol Oncol (2021) 14:73. doi: 10.1186/s13045-02101083-5

107. Li C, Yang N, Li H, Wang Z. Robo1-Specific Chimeric Antigen Receptor Natural Killer Cell Therapy for Pancreatic Ductal Adenocarcinoma With Liver Metastasis. J Cancer Res Ther (2020) 16:393-6. doi: 10.4103/jcrt.JCRT_190_20

108. Greenbaum U, Yalniz FF, Srour SA, Rezvani K, Singh H, Olson A, et al Chimeric Antigen Receptor Therapy: How Are We Driving in Solid Tumors? Biol Blood Marrow Transplant (2020) 26:1759-69. doi: 10.1016/j.bbmt. 2020.06.020

109. Liu E, Marin D, Banerjee P, Macapinlac HA, Thompson P, Basar R, et al. Use of CAR-Transduced Natural Killer Cells in CD19-Positive Lymphoid Tumors. N Engl J Med (2020) 382:545-53. doi: 10.1056/NEJMoa1910607

110. Liu E, Tong Y, Dotti G, Savoldo B, Muftuoglu M, Kondo K, et al. Cord Blood Derived Natural Killer Cells Engineered With a Chimeric Antigen Receptor Targeting CD19 and Expressing IL-15 Have Long Term Persistence and Exert Potent Anti-Leukemia Activity. Blood (2015) 126:3091. doi: 10.1182/ blood.V126.23.3091.3091

111. Senthil P, Balakrishnan H. The Engineering of Natural Killer Cells as an Emerging Adoptive Cancer Immunotherapy. J Young Investigators (2020) 38:36-42. doi: 10.22186/jyi.38.5.36-42

112. Xia J, Minamino S, Kuwabara K. CAR-Expressing NK Cells for Cancer Therapy: A New Hope. Biosci Trends (2020) 14:354-9. doi: 10.5582/ bst.2020.03308

113. Micucci F, Zingoni A, Piccoli M, Frati L, Santoni A, Galandrini R. HighEfficient Lentiviral Vector-Mediated Gene Transfer Into Primary Human NK Cells. Exp Hematol (2006) 34:1344-52. doi: 10.1016/j.exphem. 2006.06.001

114. Allan DSJ, Chakraborty M, Waller GC, Hochman MJ, Poolcharoen A, Reger $\mathrm{RN}$, et al. Systematic Improvements in Lentiviral Transduction of Primary Human Natural Killer Cells Undergoing Ex Vivo Expansion. Mol Ther Methods Clin Dev (2021) 20:559-71. doi: 10.1016/j.omtm.2021.01.008

115. Ueda T, Kumagai A, Iriguchi S, Yasui Y, Miyasaka T, Nakagoshi K, et al. Non-clinical Efficacy, Safety and Stable Clinical Cell Processing of Induced Pluripotent Stem Cell-Derived Anti-Glypican-3 Chimeric Antigen Receptor-Expressing Natural Killer/Innate Lymphoid Cells. Cancer Sci (2020) 111:1478-90. doi: 10.1111/cas.14374

116. Gong Y, Wolterink RGK, Janssen I, Groot AJ, Bos GM, Germeraad WT. Rosuvastatin Enhances VSV-G Lentiviral Transduction of NK Cells via Upregulation of the Low-Density Lipoprotein Receptor. Mol TherapyMethods Clin Dev (2020) 17:634-46. doi: 10.1016/j.omtm.2020.03.017

117. Suerth JD, Morgan MA, Kloess S, Heckl D, Neudorfl C, Falk CS, et al. Efficient Generation of Gene-Modified Human Natural Killer Cells via Alpharetroviral Vectors. J Mol Med (Berl) (2016) 94:83-93. doi: 10.1007/ s00109-015-1327-6

118. Schmidt P, Raftery MJ, Pecher G. Engineering NK Cells for CAR TherapyRecent Advances in Gene Transfer Methodology. Front Immunol (2020) 11:611163. doi: 10.3389/fimmu.2020.611163

119. Colamartino ABL, Lemieux W, Bifsha P, Nicoletti S, Chakravarti N, Sanz J, et al. Efficient and Robust NK-Cell Transduction With Baboon Envelope Pseudotyped Lentivector. Front Immunol (2019) 10:2873. doi: 10.3389/ fimmu.2019.02873

120. Gutierrez-Guerrero A, Cosset FL, Verhoeyen E. Lentiviral Vector Pseudotypes: Precious Tools to Improve Gene Modification of Hematopoietic Cells for Research and Gene Therapy. Viruses (2020) 12. doi: 10.3390/v12091016

121. Pomeroy EJ, Hunzeker JT, Kluesner MG, Lahr WS, Smeester BA, Crosby MR, et al. A Genetically Engineered Primary Human Natural Killer Cell Platform for Cancer Immunotherapy. Mol Ther (2020) 28:52-63. doi: 10.1016/j.ymthe.2019.10.009

122. Ingegnere T, Mariotti FR, Pelosi A, Quintarelli C, De Angelis B, Tumino N, et al. Human CAR NK Cells: A New Non-Viral Method Allowing High Efficient Transfection and Strong Tumor Cell Killing. Front Immunol (2019) 10:957. doi: 10.3389/fimmu.2019.00957

123. Williams JA. Improving DNA Vaccine Performance Through Vector Design. Curr Gene Ther (2014) 14:170-89. doi: 10.2174/156652321403140819122538

124. Xiao L, Cen D, Gan H, Sun Y, Huang N, Xiong H, et al. Adoptive Transfer of NKG2D CAR mRNA-Engineered Natural Killer Cells in Colorectal Cancer Patients. Mol Ther (2019) 27:1114-25. doi: 10.1016/j.ymthe.2019.03.011 
125. Hermanson DL, Kaufman DS. Utilizing Chimeric Antigen Receptors to Direct Natural Killer Cell Activity. Front Immunol (2015) 6:195. doi: 10.3389/fimmu.2015.00195

126. Li L, Liu LN, Feller S, Allen C, Shivakumar R, Fratantoni J, et al. Expression of Chimeric Antigen Receptors in Natural Killer Cells With a RegulatoryCompliant Non-Viral Method. Cancer Gene Ther (2010) 17:147-54. doi: $10.1038 / \mathrm{cgt} .2009 .61$

127. Li L, Allen C, Shivakumar R, Peshwa MV. Large Volume Flow Electroporation of mRNA: Clinical Scale Process. Methods Mol Biol (2013) 969:127-38. doi: 10.1007/978-1-62703-260-5_9

128. Huang RS, Lai MC, Shih HA, Lin S. A Robust Platform for Expansion and Genome Editing of Primary Human Natural Killer Cells. J Exp Med (2021) 218. doi: 10.1084 jem.20201529

129. Hajj KA, Whitehead KA. Tools for Translation: Non-Viral Materials for Therapeutic mRNA Delivery. Nat Rev Mater (2017) 2:1-17. doi: 10.1038/ natrevmats. 2017.56

130. Robbins GM, Wang M, Pomeroy EJ, Moriarity BS. Nonviral Genome Engineering of Natural Killer Cells. Stem Cell Res Ther (2021) 12:350. doi: 10.1186/s13287-021-02406-6

131. Pomeroy EJ, Lahr WS, Chang JW, Krueger JB, Wick BJ, Slipek NJ, et al. NonViral Engineering of CAR-NK and CAR-T Cells Using the Tc Buster Transposon System ${ }^{\mathrm{TM}}$. bioRxiv (2021). doi: 10.1101/2021.08.02.454772

132. Chauvin JM, Zarour HM. TIGIT in Cancer Immunotherapy. J Immunother Cancer (2020) 8. doi: 10.1136/jitc-2020-000957

133. Cerboni C, Fionda C, Soriani A, Zingoni A, Doria M, Cippitelli M, et al. The DNA Damage Response: A Common Pathway in the Regulation of NKG2D and DNAM-1 Ligand Expression in Normal, Infected, and Cancer Cells. Front Immunol (2014) 4:508. doi: 10.3389/fimmu.2013.00508

134. Leivas A, Rio P, Mateos R, Paciello ML, Garcia-Ortiz A, Fernandez L, et al. NKG2D-CAR Transduced Primary Natural Killer Cells Efficiently Target Multiple Myeloma Cells. Washington, DC: American Society of Hematology (2018).

135. El-Mayta R, Zhang Z, Hamilton AG, Mitchell MJ. Delivery Technologies to Engineer Natural Killer Cells for Cancer Immunotherapy. Cancer Gene Ther (2021) 28:947-59. doi: 10.1038/s41417-021-00336-2

Conflict of Interest: EH, EZ, TS-N, AH, SB, NK, and MV had compensated employment at Thermo Fisher Scientific.

Publisher's Note: All claims expressed in this article are solely those of the authors and do not necessarily represent those of their affiliated organizations, or those of the publisher, the editors and the reviewers. Any product that may be evaluated in this article, or claim that may be made by its manufacturer, is not guaranteed or endorsed by the publisher.

Copyright (C) 2021 Heipertz, Zynda, Stav-Noraas, Hungler, Boucher, Kaur and Vemuri. This is an open-access article distributed under the terms of the Creative Commons Attribution License (CC BY). The use, distribution or reproduction in other forums is permitted, provided the original author(s) and the copyright owner(s) are credited and that the original publication in this journal is cited, in accordance with accepted academic practice. No use, distribution or reproduction is permitted which does not comply with these terms. 